\title{
LEVANTAMENTO E IDENTIFICAÇÃO DE CUPINS (INSECTA: ISOPTERA) EM ÁREA URBANA DE PIRACICABA, SP
}

\author{
ELIANE SANTOS DA ROCHA ELEOTÉRIO
}

Bióloga

Orientador: Prof. Dr. EVÔNEO BERTI FILHO

Dissertação apresentada à Escola Superior de Agricultura "Luiz de Queiroz", Universidade de São Paulo, para obtenção do título de Mestre em Ciências, Área de Concentração: Ciência e Tecnologia de Madeiras.

\author{
PIRACICABA \\ Estado de São Paulo - Brasil
}

Fevereiro de 2000 
Dados Internacionais de Catalogaçāo na Publicação (CIP)

DIVISĀO DE BIBLIOTECA E DOCUMENTAÇĀO - Campus "Luiz de Oueiroz"/USP

Eleotério, Eliane Santos da Rocha

Levantamento e identificação de cupins (insecta: isoptera) em área urbana de Piracicaba, SP / Eliane Santos da Rocha Eleotério. - P Piracicaba, 2000. 102 p. : il.

Dissertação (mestrado) - - Escola Superior de Agricultura Luiz de Queiroz, 2000. Bibliografia.

1. Área urbana 2. Biodeterioração 3.Cupim 4.Edificação 5. Identificação 6. Infestação 7. Inseto-nocivo 8. Levantamento 9. Madeira 10. Materiais para construção I. Título

CDD 628.96 


\section{AGRADECIMENTOS}

Ao Prof. Dr. Evôneo Berti Filho, pela orientação e constante incentivo.

Ao Prof. Dr. Mário Tomazello Filho, Coordenador do Curso de Ciência e Tecnologia da Madeira da Escola Superior de Agricultura "Luiz de Queiroz"USP, pelo apoio constante no decorrer do curso.

Ao Prof. Dr. José Mangolini Neves, um agradecimento especial, pelo incentivo e apoio, decisivos para a realização do curso.

Ao esposo e colega Jackson Roberto Eleotério, pela colaboração em todas as fases do trabalho, sem a qual não seria possivel a conclusão do curso em tempo hábil.

Ao Dr. Luiz Roberto Fontes, pelo incentivo, sugestões e identificação dos cupins encontrados nas edificações.

Ao Prof. Dr. Antônio Tadeu de Lelis, pela colaboração na determinação da metodologia.

Ao Dr. Frederico Pimentel Gomes, pelo auxilio na determinação da metodologia e na análise estatística.

Ao Prof. Dr. Ivaldo Jankowsky e Dr. Francisco Marinconi, pelas sugestões apresentadas.

À CAPES pelo auxílio financeiro que tornou possivel a execução deste trabalho.

Aos amigos e familiares, pelo apoio.

$\dot{A}$ todas as pessoas que de alguma maneira contribuíram para a conclusão do curso. 


\section{SUMÁRIO}

\section{Página}

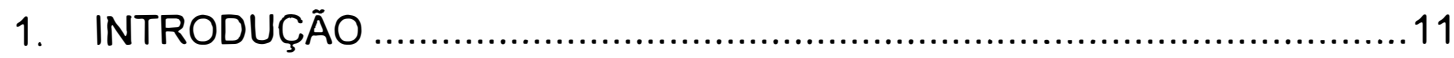

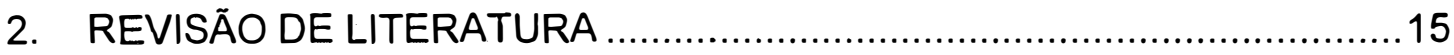

2.1. Cupins - Sistemática e Bioecologia................................................ 15

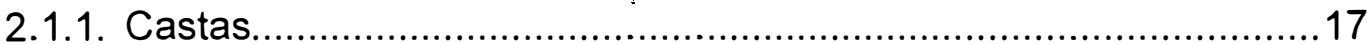

2.1.2. Fundação de novas colônias ................................................. 17

2.1.3. Ninhos......................................................................... 18

2.1.4. Critérios de Identificação ................................................... 19

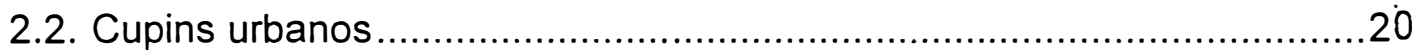

2.2.1. Cupins de madeira seca ...................................................... 21

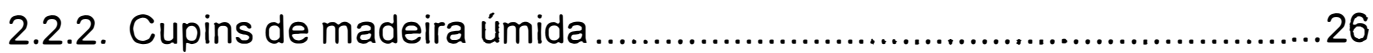

2.2.3. Cupins subterrâneos .......................................................28

2.2.4. Cupins que são pragas potenciais ........................................ 33

2.3. Como diferenciar os danos causados por cupins dos causados por outros insetos deterioradores de madeira ...................................... 34 
2.3.1. Coleópteros ou brocas de madeira

2.4. Fatores que propiciam ou que mantém as infestações por cupins nas construções urbanas 35

2.4.1. Uso de madeiras pouco resistentes e sem tratamento 35

2.4.2. Uso de técnicas construtivas inadequadas 36

2.4.3. Falta de cuidados com a arborização urbana 39

2.4.4. Utilização inadequada de materiais à base de madeira 40

2.4.5. Tratamentos curativos mal aplicados 41

3. MATERIAL E MÉTODOS 42

3.1. Caracterização do local de estudo

3.2. Critérios para a inspeção das edificações .45

3.2.1. Prédios de apartamentos 45

3.2.2. Prédios residenciais 46

3.2.3. Prédios comerciais. 47

3.3. Condução das inspeções 47

3.3.1. Cupins subterrâneos. 49

3.3.2. Cupins de madeira seca e de madeira úmida. 49

3.4. Identificação do agente causador do ataque .50

3.5. Análise dos dados .51 


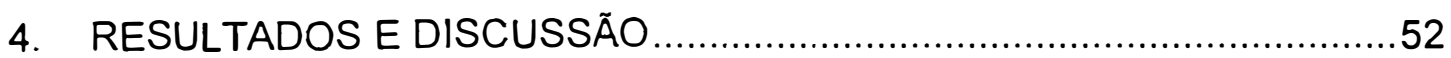

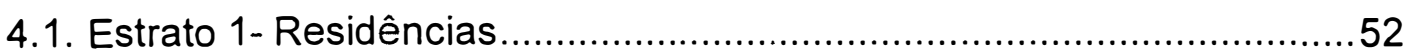

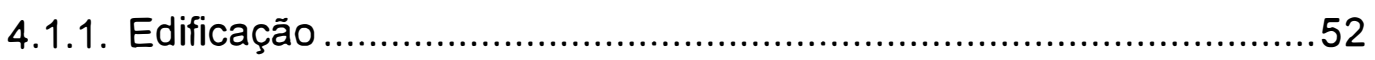

4.1.1.1. Número de edificaçōes com cupins e peças mais freqüentemente atacadas......................................................... 52

4.1.1.2. Presença de cupins e idade da edificação................................58

4.1.1.3. Número de focos e idade das edificações ................................60

4.1.1.4. Número de focos de cupins e tipo de material atacado .............61

4.1.1.5. Relação entre ocorrência de cupins e umidade .........................62

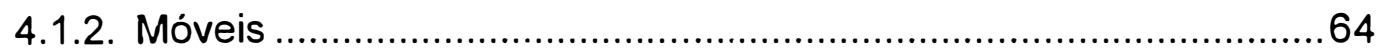

4.1.2.1. Número de focos de cupins e tipo de material atacado .............64

4.1.3. Análise conjunta da edificação e móveis ........................................65

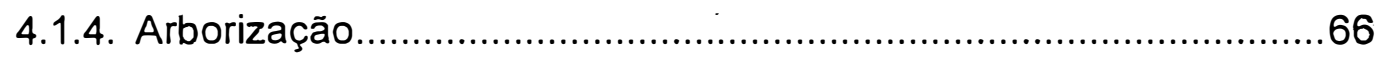

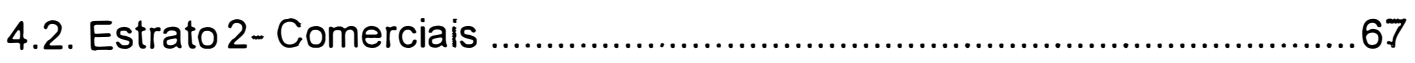

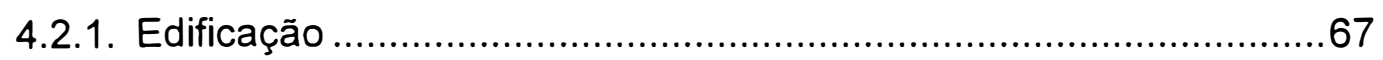

4.2.1.1. Número de edificaçōes com cupins e suas peças mais

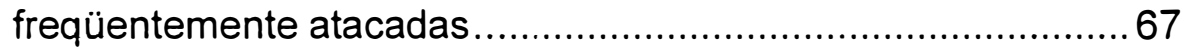

4.2.1.2. Número de focos de cupins nas edificaçōes e tipo de material

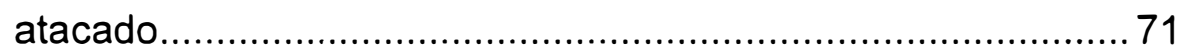

4.2.1.3. Presença de cupins e idade da edificação.................................72 
4.2.2. Móveis

4.2.3. Análise conjunta da edificação e móveis .75

4.2.4. Arborização .76

4.3. Estrato 3 - Prédios de apartamentos .76

4.3.1. Edificação .76

4.3.1.1. Número de prédios de apartamentos com cupins e suas partes mais freqüentemente atacadas 76

4.3.1.2. Número de focos de cupins nas edificações e tipo de material atacado. 77

4.3.1.3. Presença de cupins e idade da edificação. .77

4.3.1.4. Relação entre ocorrência de cupins e presença de umidade .....78

4.3.2. Móveis .80

4.3.3. Construção e móveis .80

4.3.4. Arborização .80

4.4. Espécies de cupins encontradas .80

4.4.1. Cupins de madeira seca (Cryptotermes brevis) .83

4.4.2. Cupins subterrâneos 85

4.4.3. Cupins na arborização urbana 86

4.5. Espécies de madeiras atacadas nas edificaçōes 88 
4.6. Distribuição dos diferentes grupos de cupins no bairro São Dimas 89

4.7. Outras considerações 90

5. CONCLUSÕES 94

REFERÊNCIAS BIBLIOGRÁFICAS 95 


\title{
LEVANTAMENTO E IDENTIFICAÇÃO DE CUPINS (INSECTA: ISOPTERA) EM ÁREA URBANA DE PIRACICABA, SP
}

\author{
Autora: ELIANE SANTOS DA ROCHA ELEOTÉRIO \\ Orientador: Prof. EVÔNEO BERTI FILHO
}

\section{RESUMO}

Este trabalho foi conduzido com o objetivo de realizar o levantamento e a identificação das espécies de cupins presentes nas edificações do Bairro São Dimas, na cidade de Piracicaba, São Paulo. Foram determinadas as espécies mais freqüentes e estabelecidas as relações entre ocorrência de cupins e idade das edificações, tipo de material utilizado na construção, cuidados preventivos quando da execução desta, excesso de umidade na madeira e sanidade da arborização urbana. Os imóveis foram selecionados por amostragem e as espécies de cupins encontradas infestando as edificações foram Cryptotermes brevis (Walker) e Coptotermes havilandi (Holmgren), sendo que a primeira espécie foi encontrada na maior parte das edificações inspecionadas. Constatou-se que o risco de infestações, bem como o número de focos de cupins tendem a aumentar com a idade das construções. Nas edificações residenciais a ocorrência de cupins tende a aumentar com a umidade da madeira. Não houve relação entre ocorrência de cupins em árvores e as infestações das edificações. 


\title{
SURVEY AND IDENTIFICATION OF TERMITES (INSECTA: ISOPTERA) IN URBAN AREA OF PIRACICABA, STATE OF SÃO PAULO, BRAZIL
}

\author{
Author: ELIANE SANTOS DA ROCHA ELEOTÉRIO \\ Adviser: Prof. EVÔNEO BERTI FILHO
}

\section{SUMMARY}

This research deals with the occurrence of termites in a urban area of Piracicaba City, State of São Paulo, Brazil. Samples of home and commercial buildings were surveyed and the termites collected were identified. Termite occurrence was related to building age, type of material used in buildings and preventive care upon construction, humidity content of wood and health condition of the urban trees. The most frequent species were the drywood termite, Cryptotermes brevis (Walker), and the subterranean termite Coptotermes havilandi (Holmgren). It was observed that the risck of termite attacks, as well as the number of attacks per building showed a tendency to increase whith the age of the buildings. However no relationship was observed between the occurrence of termites in the trees nearby with the attack in the buildings. 


\section{INTRODUÇÃO}

A madeira é um material extremamente versátil que pode ser utilizado para os mais diversos fins: energético, na construção civil, em obras de arte, na indústria moveleira, entre outros. A ampla utilização da madeira pelo homem é determinada por uma série de caracteristicas apresentadas por este material, dentre as quais estão: baixo custo, grande disponibilidade, alta resistência em relação ao seu peso, excelente trabalhabilidade, uma gama elevada de cores e texturas tornando-a agradável esteticamente, requer baixo insumo energético para sua produção, é renovável e pode ser reciclada (Koch, 1992 e Oliveira et al., 1986).

Além disso, o uso da madeira como material para a construção civil está ganhando espaço no mercado e a sua demanda tende a aumentar futuramente como uma forma de minimizar problemas ambientais, pois de acordo com Costa (1998) e Zerbe (1992), na sua produção ocorre a captura de $\mathrm{CO}_{2}$ pela árvore, que é retido na constituição química da madeira. Desta forma, toda a madeira empregada em construções estaria contribuindo para a diminuição do $\mathrm{CO}_{2}$ livre na atmosfera.

Contrapondo-se a inúmeras vantagens apresentadas pela madeira e seus derivados determinantes para a sua ampla utilização, existe a biodeterioração, pois segundo Oliveira et al. (1986), a madeira é um material de origem orgânica e como tal está sujeita a deterioração por agentes biológicos (bactérias, fungos, insetos e brocas marinhas). 
Os organismos biodeterioradores, por apresentarem características morfológicas, fisiológicas e comportamentais especiais, são capazes de utilizar a madeira como substrato, abrigo e alimento. Neste contexto, destaque especial é dado aos cupins ou térmites, que devido a capacidade de digerir celulose proporcionada por fauna microbiológica simbionte presente em seu intestino, são atraídos por todo o material de origem celulósica, como a madeira em seu estado bruto, papel, tecidos e outros (Grassé, 1982; Oliveira et al., 1986).

Em área urbana, de acordo com Fontes (1995a), são considerados dois grupos de cupins: os que são benéficos e fazem parte da fauna autóctone nos grandes parques, reservas e jardins, sendo importantes para a manutenção da homeostase ambiental e os que ocasionam prejuízos econômicos pelos danos que causam no madeiramento das construções, visto que, de maneira geral, apenas são percebidos quando já houve comprometimento da estrutura das edificações. O autor acredita que o estabelecimento dos cupins nas cidades é devido à diminuição de áreas naturais, pela implementação de monoculturas, plantio de florestas de espécies introduzidas e ao alastramento das cidades, fazendo com que os cupins, em busca de alimento e refúgio, estabeleçam-se nas praças e construções dos grandes centros urbanos, onde algumas espécies tornam-se pragas importantes. São várias as causas que têm levado os cupins a terem sucesso em áreas urbanas sendo que a grande quantidade de áreas sombreadas, utilização de madeiras não resistentes ou não tratadas como material de construção, são alguns exemplos.

Para Robinson (1996), o status de peste dos térmitas em meio urbano é baseado no impacto econômico do dano que eles causam às edificações, que é expresso em custos com prevenção, controle e reparo do dano estrutural. O autor cita a ocorrência de cinco espécies de térmitas de importância econômica 
nos Estados Unidos, onde são responsáveis por prejuizos de um bilhão de dólares por ano em áreas urbanas e rurais, e 20 espécies na Austrália cujo controle curativo custa cem milhões de dólares por ano. Na região sul da Flórida os gastos com controle de cupins de madeira seca chegam a aproximadamente trinta milhões de dólares ao ano.

No Brasil existem poucas espécies de cupins considerados prejudiciais às edificações de área urbana, cuja biologia é pouco conhecida. No entanto, Edwards \& Mill (1986), Lelis (1995); Waller \& La Fage (1986) e Forti \& Andrade (1995) consideram necessário o conhecimento da biologia dos cupins para obter-se sucesso no seu controle tanto curativo como preventivo.

Segundo Fontes (1995b), o conhecimento do nome da espécie do cupim causador dos danos, promove o acesso aos conhecimentos acumulados no mundo sobre esta espécie, auxiliando no diagnóstico e controle de infestações. O autor chama a atenção para o fato do número de espécies de cupins existentes no Brasil estar subestimado e afirma que apesar de serem registradas 200 espécies, há espécies descritas que ainda não foram assinaladas no Brasil, e muitas espécies novas a serem descritas.

Para Forti \& Andrade (1995), apesar dos cupins ocorrerem em grande quantidade e de provocarem danos consideráveis, em área urbana, principalmente na região sudeste, os cupins não têm despertado $\circ$ interesse dos pesquisadores brasileiros, sendo ainda pouco estudados.

Partindo do princípio de que é a partir da identificação das espécies de cupins que causam prejuízos é que se torna viável o seu controle, esta pesquisa foi conduzida com $\circ$ objetivo de realizar o levantamento $e$ a identificação das espécies de cupins presentes nas edificações do Bairro São Dimas, na cidade de Piracicaba, São Paulo, visando: 
-determinar as espécies de cupins mais freqüentes;

- determinar os locais preferenciais para o estabelecimento de novos focos de infestação nas edificações;

- verificar a existência de correlação entre a ocorrência de cupins e:

-tipo de material utilizado na construção (madeira maciça ou reconstituida);

-cuidados preventivos quando da execução da obra;

-idade da edificação;

-ocorrência de umidade;

-sanidade da arborização urbana. 


\section{REVISÃO DE LITERATURA}

\subsection{Cupins - Sistemática e Bioecologia}

Os cupins são insetos sociais que formam colônias de indivíduos interdependentes entre si, onde há sobreposição de gerações e cuidados com a prole. Sua estrutura social é composta por indivíduos que se desenvolvem por paurometabolia e compreende machos e fêmeas que se distribuem em categorias ou castas (Grassé, 1982; Oliveira et al., 1986).

Os cupins ocorrem nas áreas tropicais e temperadas do mundo, entre os paralelos $52^{\circ} \mathrm{Ne} 45^{\circ} \mathrm{S}$ (Fontes, 1995b).

A ordem Isoptera conta com mais de 2000 espécies descritas, que são distribuídas em sete familias: Kalotermitidae, Termopsidae, Rhinotermitidae, Serritermitidae e Termitidae. Na Região Neotropical ocorrem as familias: Kalotermitidae, Termopsidae, Rhinotermitidae, Termitidae e Serritermitidae. Esta última representada por uma única espécie e de ocorrência apenas no Brasil. Nas Américas, excluindo-se os fósseis, ocorrem 84 gêneros em 5 famílias com 514 espécies, sendo que no Brasil relatou-se a existência de 200 espécies (Araújo, 1977 e Fontes, 1983).

Segundo Oliveira et al.(1986) e Krishna (1970), considerando-se o aspecto evolutivo, os cupins podem ser divididos em dois grupos: cupins 
superiores e inferiores. Os cupins superiores são os pertencentes à família Termitidae, as demais familias pertencem ao grupo dos cupins inferiores. Os autores descrevem como características de cupins primitivos: pequeno número de indivíduos em colônias maduras, ninhos pouco elaborados, utilizar a madeira como alimento principal, degradar a celulose através de protozoários simbiontes e possuir castas pouco definidas; e como características de cupins superiores: ocorrência de colônias muito populosas, ninhos bem elaborados, utilizar-se de outras fontes de alimento que não seja madeira, degradar a celulose através de bactérias e de possuir castas bem definidas.

Os térmitas possuem alimentação bastante variada entre as espécies e nem todos possuem hábitos xilófagos. Muitas espécies se alimentám de matéria orgânica em decomposição, madeiras deterioradas por fungos e outras são forrageiras ou cultivam fungos (Edwards \& Mill, 1986 e Oliveira et al., 1986).

Segundo Grassé (1982), os cupins são fototrópicos negativos e portanto, vivem confinados no interior dos ninhos e, de maneira geral, não possuem olhos sendo que os quimiorreceptores, localizados nas extremidades das antenas em conjunto com pêlos sensoriais distribuídos pelo seu corpo, são os responsáveis pela percepção dos estímulos olfato e tato. De acordo com o autor, os cupins também possuem sensilas nos palpos maxilares e labiais, e a importância da olfação é evidenciada pela detecção de alimento ou de outras substâncias pelas quais são repelidos quando nocivas.

Para Edwards \& Mill (1986) e Nutting (1970), uma colônia só pode ser considerada madura quando for capaz de produzir todas as castas características da espécie, inclusive os alados. O tempo levado por uma colônia para atingir a maturidade varia de acordo com a espécie e com fatores ambientais, podendo ser de 3 a 6 anos. 
O potencial de longevidade das colônias de cupins é difícil de ser estimado, mas parece ser ilimitado dada a capacidade da colônia em gerar reprodutores secundários sempre que necessário (Wilson, 1974).

\subsubsection{Castas}

Por serem insetos sociais, assim como as formigas cortadeiras e as abelhas, os térmitas possuem divisão de trabalho em castas, morfológica e funcionalmente diferentes. A população de cupins é, geralmente, constituída por três castas: operários, soldados e reprodutores.

\subsubsection{Fundação de novas colônias}

Geralmente a fundação de uma colônia ocorre a partir da produção de imagos por colônias maduras, que após a revoada, pousam, perdem as asas e formam os pares reais (Oliveira et al., 1986).

A revoada é possivel porque os alados, ao longo de seu desenvolvimento, adquirem fototropismo positivo o que possibilita a sua saída da colônia de origem. O fototropismo positivo é mais acentuado no momento da revoada sendo que após a perda das asas os cupins tornam-se fototrópicos negativos, como as demais castas que compõem a colônia (Grassé, 1984 e Oliveira et al., 1986).

O sucesso na dispersão dos térmitas, para Nutting (1970), depende de condições meteorológicas favoráveis para o vôo (temperatura, umidade do ar, luminosidade, entre outras), número de alados produzidos e taxa de predação.

Segundo Grassé (1949) e Grassé (1984), após a formação do par real, há a escavação de uma câmara nupcial e a amputação parcial mutua das antenas 
pelo casal. Na câmara nupcial ocorrerá a primeira cópula e postura dos primeiros ovos.

Com o surgimento dos primeiros operários o casal real passa a ter somente a função reprodutiva. As cópulas são periódicas e o abdome da fêmea sofre uma hipertrofia, decorrente da pressão exercida pelas bainhas ovarianas que vão se enchendo de ovos. Este fenômeno é denominado fisogastria (Grassé, 1949 e Oliveira et al., 1986).

\subsubsection{Ninhos}

Em todos os térmitas, de acordo com Noirot (1970), os ninhos são isolados do meio externo e a comunicação deste com o meio interno nunca é direta, a não ser em momentos especiais como ocorre em épocas de revoada, para a saída dos alados. O autor salienta que este enclausuramento se deve a necessidade de proteção contra os movimentos do ar e de manutenção de condições de umidade, temperatura e atmosfera interna necessárias para o desenvolvimento normal da colônia.

Os térmitas, de maneira geral, são considerados excelentes arquitetos tanto pela grande variedade de tipos como pela complexidade das suas construções.

Segundo Lee \& Wood (1971), as proporções entre areia, silte e argila e sua distribuição no perfil do solo é um fator limitante para a construção dos ninhos de cupins subterrâneos. Solos com boa quantidade de argila são mais facilmente trabalhados pelos cupins e os solos arenosos dificultam a sustentação dos ninhos e dos túneis.

Para Noirot (1970), ao longo do tempo as construções dos térmitas têm evoluído passando por modificações contínuas. Devido a estas modificações, 
existem diversas formas intermediárias de ninhos. O autor, a fim de facilitar o entendimento, divide os tipos de ninho em cinco categorias principais: ninhos dentro da madeira, ninhos subterrâneos, ninhos epígeos, ninhos arbóreos e inquilinismo.

\subsubsection{Critérios de Identificação}

De acordo com Fontes (1995b), para identificação dos térmitas até gênero e espécie, se utiliza principalmente a casta dos soldados, com exceção dos Apicotermitinae. $O$ autor afirma não haver até o presente momento uma chave de identificação para todos os gêneros neotropicais.

Para a realização da identificação, Edwards \& Mill (1986), recomendam que os cupins, no momento da coleta, devem ser manuseados com cuidado e colocados imediatamente em recipiente com álcool a $75 \%$. Se possivel devem ser coletados o rei e a rainha ou 5-10 reprodutores alados ou ninfas em último estágio de diferenciação (com asas desenvolvidas), 5-10 operários, 5-10 soldados e amostras do material danificado. Deve-se fotografar o material danificado e os indícios deixados pelos cupins.

Segundo Fontes (1995b), atualmente a sistemática dos cupins não se resume a utilização de características morfológicas externas, têm-se utilizado também para a identificação até gênero, características morfológicas do tubo digestivo da casta de operários. Segundo o autor, o padrão de arquitetura dos ninhos também tem auxiliado a sistemática visto que algumas espécies possuem padrões de construção bastante peculiares, que em conjunto com outras características, permitem a sua identificação com maior segurança. Também têm-se utilizado, embora não façam parte da rotina de identificação, particularidades de comportamento associadas a morfologia e peculiaridades da quimica das secreções de defesa do soldado. 


\subsection{Cupins urbanos}

Robinson (1996) considera os térmitas um dos mais bem sucedidos entre os insetos sociais, devido a longa vida de suas colônias e por utilizarem celulose como alimento. Este material é um dos mais abundantes da face da Terra. Apesar disso, poucos térmitas têm tido sucesso na transição do ambiente natural para o ambiente urbano, e o sucesso de algumas espécies tem sido relacionado a sua habilidade em se adaptar às mais variadas condições existentes no meio urbano. Segundo o autor, as construções modernas, por possuirem aparelhos de ar condicionado ou aquecedores que mantém as temperaturas constantes, favorecem a manutenção de cupins subterrâneos em grande atividade durante o ano todo.

Waller \& La Fage (1986) acreditam que a eliminação de competição e a eliminação dos predadores pelo homem facilitaram a proliferação dos térmitas em áreas urbanas.

Muitas espécies adaptadas ao ambiente urbano têm desenvolvido estratégias de vôo que evitam a predação por pássaros e outros animais. Esses cupins realizam as revoadas ao entardecer, quando os seus predadores estão diminuindo suas atividades, e por serem pequenos e de coloração escura passam desapercebidos em locais pouco iluminados (Robinson, 1996).

De acordo com Lin-RiZhao (1996), a composição das espécies e adaptabilidade dos Isoptera a novos ambientes varia entre regiões, altitudes e nichos.

Ataques devastadores realizados por cupins, tanto subterrâneos como de madeira seca, têm sido relatados em todo o mundo. Harris (1971) relata danos em documentos, livros, madeiras de construções e materiais de origem 
orgânica, causados por Reticulitermes na Europa e nos Estados Unidos, Coptotermes na Austrália, Ásia e parte da África, Macrotermes e Odontotermes na África do Sul, Índia e sudeste da Ásia, Mastotermes no norte da Austrália e Cryptotermes nos países tropicais e região costeira dos continentes.

Um dos casos mais alarmantes de ataque de cupins ocorre na África do Sul, onde se tem relatado grande demanda de madeira para os reparos nas construções dos habitantes locais o que provocou, no decorrer de alguns anos, a devastação das florestas naturais. A diminuição de florestas naturais é reparada pelo reflorestamento com espécies exóticas, de crescimento mais rápido, cujas mudas e sementes também são severamente atacadas por cupins (Muller et al., 1997 e Wood \& Pearce, 1991).

Fowler \& Forti (1990) relatam danos causados por cupins em monumentos históricos e em obras de arte sacra em Parati, Ouro Preto, Bertioga, Itu, Cananéia e Olinda.

Em áreas urbanas, os danos causados em construções são atribuídos a cupins pertencentes a três grupos: cupins de solo ou subterrâneos, cupins de madeira úmida e cupins de madeira seca. No Brasil, os ataques mais freqüentes têm sido ocasionados por cupins de apenas dois grupos: cupins subterrâneos e cupins de madeira seca (Lelis, 1976).

\subsubsection{Cupins de madeira seca}

Os cupins de madeira seca pertencem a familia Kalotermitidae e têm sido assinalados como grandes causadores de danos em madeiras da estrutura de edificações, em móveis, livros, tecidos e outros materiais de origem celulósica em área urbana em todo o mundo (Harris, 1971). 
As colônias de cupins de madeira seca, segundo Marer (1991), infestam madeira seca, não apodrecida, estrutural, móveis, ramos de árvores vivas em locais sombreados, árvores em pomares, postes e madeiras armazenadas. A partir dessas áreas, reprodutores alados migram para novas construções e outras estruturas em dias ensolarados nos meses chuvosos. Segundo o autor, as colônias desses cupins geralmente são pequenas, em torno de 1000 individuos que vivem em peças de madeira, móveis ou peças de acabamento, que podem ser acidentalmente transportados pelo homem implicando na sua ampla área de distribuição.

Os cupins pertencentes a esse grupo têm baixo requerimento de umidade e possuem grande tolerância às condições secas por períodos prolongados. $A$ água pode ser obtida diretamente da madeira que mesmo sendo em pequena quantidade é o suficiente graças a mecanismos especiais desenvolvidos para reduzir a perda de água. Dentre esses mecanismos o de recuperação de grande parte da água do material fecal (antes de evacuar) é um dos mais importantes (Edwards \& Mill, 1986; Rudolph et al., 1990 e Waller \& La Fage, 1986). Os autores afirmam que a umidade relativa do ar, por fornecer umidade à madeira, é indiretamente fonte de água para os cupins.

Segundo Edwards \& Mill (1986) e Robinson (1996), Cryptotermes brevis (walker) é considerada uma das espécies de cupins de madeira seca mais destrutivas do mundo e é também a mais amplamente distribuída. Os autores consideram que esta espécie, de origem indiana, é extraordinariamente apta a se adaptar em todos os países por onde têm sido levada.

Steward (1983) comparou Cryptotermes brevis (Walker) com Cryptotermes dudleyi (Banks) e Cryptotermes havilandi (Sjöstedt), quanto a adaptação às diferentes condições climáticas e constatou que $C$. brevis sobrevive melhor tanto em condições quentes-secas como em frias-úmidas. 
Segundo o autor, a ampla distribuição da espécie parece estar relacionada à sua habilidade de se submeter a aclimatação e de alimentar-se eficientemente em umidades relativas tanto médias (cerca de 60\%) como altas (cerca de 90\%).

Dentre os cupins de madeira seca, as espécies que mais causam danos no mundo pertencem ao gênero Cryptotermes, sendo que no Brasil, C. brevis é citada como praga importante (Araújo, 1980).

Segundo Araújo (1970), Cryptotermes brevis foi assinalado no Brasil pela primeira vez em 1957. O autor relata a ocorrência desta espécie em São Paulo, nas cidades de Limeira, Itú, Piracicaba e Campinas.

Araújo (1977) e Fontes (1983) consideram Cryptotermes brevis como a principal espécie de cupim de madeira seca vista como praga em construções do sudeste brasileiro.

Segundo Fontes (1998), a espécie Cryptotermes brevis ocorre da região Sul à Região Norte do Brasil e infesta apenas madeiramento interno das edificações.

De acordo com Steward (1982), as colônias de Cryptotermes brevis que forem eventualmente transportadas pelo homem, dependerão do vôo de dispersão dos imagos para estabelecerem novas infestações. Para o autor, esta espécie tem atingido grande sucesso em ambientes urbanos devido a sua capacidade de reproduzir-se em condições de umidade moderadamente baixas $\left(60-70 \%\right.$ UR) e de temperaturas elevadas $\left(29-31^{\circ} \mathrm{C}\right)$.

O sinal mais característico de infestação por térmitas de madeira seca é a presença de grânulos fecais, que são colocados para fora da peça atacada. Quando as colônias são pequenas, a quantidade de grânulos fecais eliminados para fora da colônia é minima o que dificulta sua detecção. Esses grânulos são 
secos, com menos de 1 milimetro, e apresentam a coloração da madeira da qual os cupins se alimentam (Edward's \& Mill, 1986; Oliveira et al., 1986; Su \& Scheffrahn, 1990 e Van Den Meiracker, 1998).

Segundo Marer (1991), os resíduos fecais desses cupins possuem características específicas: são alongados (cerca de $0,08 \mathrm{~mm}$ de comprimento), com extremidades arredondadas e com seis sulcos ou depressões, separadas por seis arestas longitudinais achatadas. $O$ autor salienta que quando inspecionando cupins de madeira seca, além de constatar a presença dos grânulos fecais, deve-se verificar a ocorrência de tampões nos orifícios por onde os cupins jogam esses resíduos para fora da peça infestada. A coloração da substância utilizada para o fechamento assemelha-se à cor da madeira atacada o que dificulta a visualização de tais aberturas.

Após a localização dos orifícios, devem ser feitas sondagens em peças de madeira próximas a atacada, aplicando-se batidas com chave de fenda, "picador de gelo" ou faca. A emissão de um som oco é indício da existência de galerias internas, desta maneira pode-se estimar a extensão do ataque (Edwards \& Mill, 1986 e Koehler, 1996).

Segundo Potter (1997), a presença de formas aladas ou acúmulo de asas caídas no interior da construção, revelam a ocorrência de revoadas e podem ser indício de infestação.

É de grande importância, portanto, que se conheça a conformação das asas dos cupins que pertençam aos diferentes grupos: Os cupins de madeira seca e de madeira úmida apresentam venação complexa, com nervuras transversais entre a nervura costal (que forma a margem anterior da asa ou margem costal); os cupins subterrâneos possuem uma nervura paralela a 
nervura costal e ambas fortemente esclerotizadas (Scheffrahn \& Su, 1999; Weesner, 1969 e Woodrow et al., 1999) (Figuras 1 e 2).

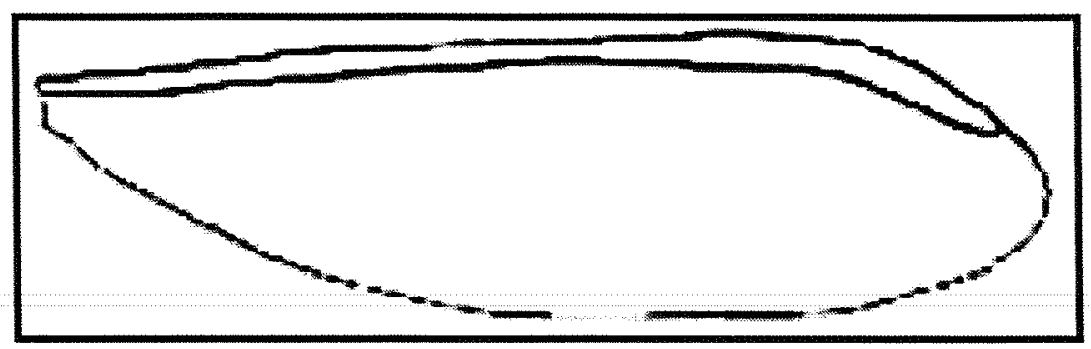

FIGURA 1. Esboço de asa de cupins subterrâneos com as duas veias paralelas (Koehler et al., 1990; Scheffrahn \& Su, 1999 e Woodrow et al., 1999).

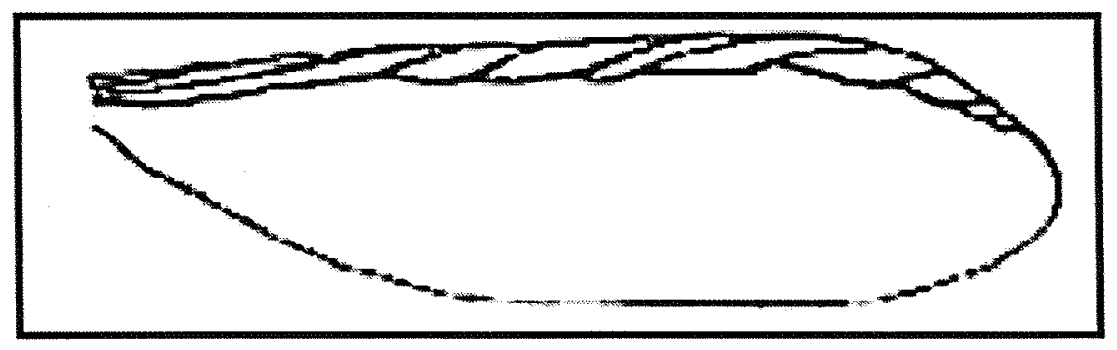

FIGURA 2. Esboço de asa de cupim de madeira seca ou de madeira úmida, com as nervuras transversais ((Koehler et al., 1990; Scheffrahn \& Su, 1999 e Woodrow et al., 1999).

De acordo com Koehler (1997), nas peças atacadas por cupins de madeira seca, os túneis e as galerias são feitos transversalmente à grã da madeira e os cupins destroem tanto o lenho juvenil quanto o lenho tardio. Examinando-se essas peças, quando muito danificadas, essas características podem ser observadas.

Segundo Marer (1991) existem outros métodos de detecção de cupins de madeira seca além dos citados anteriormente. Estes métodos incluem a utilização de cães, detetores de odor (emissão de metano pelos cupins) e sensores de vibração. Dentre estes métodos, o único considerado como efetivo é a utilização de sensores de vibração, mas seu custo é alto o que o torna 
inviável. Portanto, o método mais utilizado para a inspeção para cupins de madeira seca é o da busca visual.

No momento da inspeção devem ser feitos diagramas da edificação indicando todos os locais onde os cupins estão presentes.

\subsubsection{Cupins de madeira úmida}

Apesar dos cupins de madeira úmida não terem sido relatados no Brasil como pragas em construções, é importante salientar que esses cupins, assim como os cupins de madeira seca, também jogam grânulos fecais para o exterior da madeira atacada. Desta forma, se as espécies causadoras do ataque forem confundidas, a tomada de decisão para a adoção de medidas de controle pode ser equivocada.

Segundo Edwards \& Mill (1986), esses cupins estão associados a madeiras atacadas por fungos e a aparência do dano varia de acordo com o nivel do apodrecimento e a quantidade de umidade presente na madeira.

De acordo com Marer (1991), as colônias de cupins de madeira úmida geralmente são instaladas em madeiras enterradas, mas podem infestar madeiras com alto teor de umidade sem contato com o solo. Devido a sua necessidade de altos teores de umidade, os cupins de madeira úmida ocorrem em locais frescos e úmidos, por isso, são pragas freqüentes em construções de áreas costeiras. O autor cita a espécie Zootermopsis nevadensis (como praga nas regiões litorâneas de Nevada, e a espécie Zootermopsis angusticollis como de grande ocorrência em regiões montanhosas ao longo da costa da Califórnia.

De acordo com Koehler (1997), assim como para cupins de madeira seca, um sinal importante da infestação por cupim de madeira úmida é a presença de pequenos grânulos fecais jogados para fora das peças atacadas. Esses 
grânulos são visualizados em locais secos, lamacentos ou encharcados. Segundo o autor, sondagens para encontrar-se galerias internas através de sons ocos também devem ser realizadas.

As diferenças morfológicas entre os grânulos fecais eliminados por cupins de madeira seca e de madeira úmida são de grande importância. Os excrementos dos cupins de madeira úmida, assim como os dos cupins de madeira seca, são alongados e com extremidades arredondadas, mas as arestas que separam as depressões laterais não são proeminentes (Edwards \& Mill, 1986 e Marer, 1991). Estas diferenças podem ser observadas na Figura 3.

Ao se observar o material danificado por esses cupins, constata-se que a escavação das galerias também são transversais á grã da madeira e tanto o lenho juvenil como o tardio são atacados (Koehler, 1997).

De acordo com Edwards \& Mill (1986), em madeiras podres, as galerias são grandes e freqüentemente abertas transversalmente a grã e no lenho inicial, assemelhando-se às feitas pelas formigas carpinteiras. 


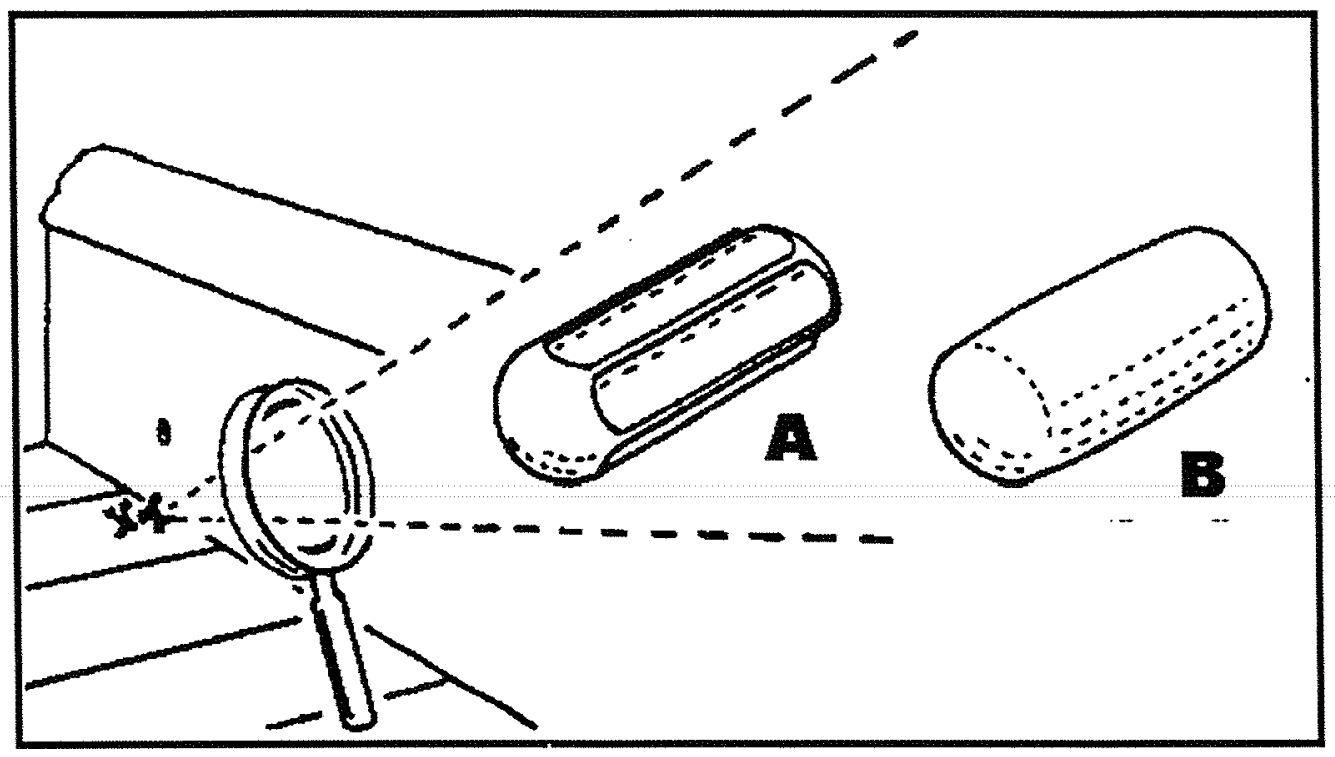

FIGURA 3. Representação de resíduo fecal de cupim de madeira seca $(A)$ e de madeira úmida (B) (Marer, 1991).

No momento da inspeção também devem ser feitos diagramas da edificação indicando todos os locais onde os cupins estão presentes.

\subsubsection{Cupins subterrâneos}

Os cupins chamados de subterrâneos pertencem a familia Rhinotermitidae e são os que causam danos mais significativos em edificações em áreas urbanas (Harris, 1971).

A dispersão destes cupins se dá através das revoadas e da formação de casais que fundarão uma nova colônia. Contudo, operários de um ninho já estabelecido no solo, podem infestar uma edificação a procura de alimento (Oliveira et al. 1986).

De acordo com Robinson (1996), se uma edificação estiver no território de forrageamento de uma colônia, os operários utilizam-se de pequenos espaços da edificação que permitam o contato com os materiais celulósicos existentes 
no interior da construção, principalmente na sua estrutura. Esses espaços podem ser, aberturas de tubulações e conduites elétricos na fundação, pequenas rachaduras nas paredes, através de juntas de dilatação de vigas, e outros, onde os cupins tenham a possibilidade de construir seus tubos do solo até $\mathrm{o}$ alimento.

Os cupins subterrâneos Coptotermes formosanus (Shiraki) constróem grandes colônias que, segundo Su \& Scheffrahn (1988), podem se utilizar de várias fontes de alimento em construções próximas e percorrer em torno de $100 \mathrm{~m}$ em busca de alimento.

Para Su \& Tamashiro ${ }^{1}$, citados por Su \& Scheffrahn (1990), as colônias e o território de forrageamento do cupim subterrâneo Coptotermes formọsanus são muito grandes e área potencial para o forrageamento, pode atingir $10 \mathrm{~m}$ de profundidade e $200 \mathrm{~m}$ de extensão ao redor da construção atacada.

Haagsma \& Rust (1995) verificaram que a atividade de forrageamento de Reticulitermes hesperus depende diretamente da temperatura e da umidade. Os autores afirmam que populações urbanas desta espécie possuem colônias maiores, têm maior atividade de forrageamento e são menos afetadas por fatores bióticos do que populações de áreas rurais.

De acordo com Howard et al. (1982), a temperatura, o tipo de solo e a umidade são os fatores que mais influenciam no sucesso do estabelecimento de colônias de Reticulitermes em áreas urbanas.

1 SU, N-Y. \& TAMASHIRO, M. An overview of the Formosan subterranean termite in the world. In: TAMASHIRO, M. \& SU, N-Y. Biology and control of the Formosan subterranean termite Honolulu: College of Trop. Agr. Human Resources/ Univ. of Hawaii. p.3-15. 
A necessidade de água dos cupins subterrâneos é grande e eles necessitam de fontes disponiveis de umidade. Em pesquisa realizada com espécies de Rhinotermitidae, Mastotermitidae e Nasutitermes nigriceps, Rudolph et al. (1990), verificaram que os cupins detectam rapidamente a água oferecida e logo em seguida a bebem, comprovando a sua grande necessidade de água.

Coptotermes formosanus foi a mais prejudicial das espécies de cupins subterrâneos encontrada na China por Lin-RiZhao et al. (1996).

Segundo Araújo (1980), Bandeira et al. (1989), Edwards e Mill (1986), Harris (1971), Lelis (1995), Mariconi et al. (1980), dentre os cupins subterrâneos, os pertencentes ao gênero Coptotermes são os que causam mais prejuízos em edificações urbanas de outros países e de várias regiões do Brasil.

No Brasil, o cupim subterrâneo citado como o causador de danos mais expressivos em construções na região sudeste é a espécie oriental Coptotermes havilandi (Fontes, 1995c),

Araújo (1970), relata a ocorrência de Coptotermes havilandi pela primeira vez no Brasil, na cidade do Rio de Janeiro em 1923 e em Santos, São Paulo em 1934.

Outras espécies de cupins subterrâneos que vêm demonstrando ser uma praga em potencial no Brasil, pertencem ao gênero Heterotermes e vêm representando risco a prédios em João Pessoa (Bandeira et al. 1989).

Quando suspeita-se de uma infestação por cupins subterrâneos, deve-se verificar a presença desses cupins no local. Para isto é necessário que se tenha conhecimento sobre as espécies de cupins que atacam construções e 
sobre seus hábitos, evitando que se passem desapercebidos quaisquer vestígios de sua presença, favorecendo assim o alcance de solução correta para o controle da infestação, se for o caso.

De acordo com Fontes (1995a), a detecção de infestação por cupins subterrâneos, demora a ser descoberta por detalhes da biologia desta espécie, pois possuem hábitos discretos apesar de ter grandes populações.

Para Oliveira et al. (1986), um dos sinais de possiveis infestações por térmitas subterrâneos é a ocorrência de revoadas em árvores próximas à construção.

Os cupins subterrâneos constróem túneis, geralmente feitos com terra, saliva e fezes que têm a função de proteger os cupins da baixa umidade do ar e da predação. A presença desses tubos é, segundo Su \& Scheffrahn (1990), um dos principais indícios de infestação.

De acordo com Potter (1997) e Myles (1999), os cupins podem construir seus túneis dentro das paredes, nas fundações ou em juntas dos pisos. Muitos tubos são construídos projetando-se em fendas nas paredes e em juntas de dilatação de vigas. Para verificar se os túneis estão ativos deve-se fazer aberturas nos mesmos e verificar a presença de cupins. Tubos antigos são ressecados e desabam facilmente.

Potter (1997) chama a atenção para a ocorrência de tubos que partam do teto da edificação, o que pode indicar uma infestação secundária (sem contato com o solo). Para o autor, a fonte de infestação é dificil de localizar e a inspeção minuciosa pode requerer a remoção de tapumes, abertura de pisos e paredes. 
Outra maneira de identificar o dano causado por cupins subterrâneos, segundo Koehler (1996), é o fato dos mesmos se alimentarem apenas do lenho juvenil e de fazerem passagens pela madeira do lenho tardio seguindo a grã da madeira. Estas características de ataque podem ser observadas abrindo-se uma peça atacada.

A presença de peças de madeira com superfícies rachadas ou irregulares nas construções são, de acordo com Edwards \& Mill (1986), indícios de infestações por cupins subterrâneos.

Quando os danos nas peças de madeira não são observados externamente, Marer (1991) indica algumas técnicas para detectar atividades de cupins utilizadas nos Estados Unidos, que são as consideradas mais modernas: uso de cães farejadores, detetores de ruídos e detetores de odor.

Segundo Myles (1999), a fim de acessar materiais de origem celulósica, os cupins subterrâneos abrem caminhos em materiais não celulósicos, como poliestireno, plásticos, cabos subterrâneos, reboco entre outros. Portanto devese observar danos nesses materiais quando há suspeitas de infestação.

Após a inspeção, deve ser feito um relatório técnico que contenha a descrição do problema, a intensidade do ataque com a indicação precisa dos locais onde foi observada a presença dos cupins. É necessário principalmente em prédios de apartamentos a obtenção das plantas da sua construção. A verificação de caixões perdidos, por exemplo, bastante atrativo para a instalação de colônias. A confecção de croquis da edificação detalhando os locais onde os cupins estão presentes auxiliam bastante na definição das estratégias para o seu controle. 


\subsubsection{Cupins que são pragas potenciais}

Os cupins que são consideradas pragas potenciais são os que até o momento não foram relatados como causadores de danos expressivos em área urbana. No entanto, provavelmente por processos de adaptação ao menor espaço para sua dispersão vêm se aproximando das cidades em busca de locais para nidificação e de novos recursos alimentares.

As espécies citadas como as que podem vir a serem pragas, pertencem ás famílias Termopsidae, Rhrinotermitidae e Termitidae, levando-se em consideração as espécies que vêm sendo aos poucos vistas atacando o madeiramento de construções (Harris, 1971).

Heterotermes tenuis e Heterotermes longiceps constróem ninhos subterrâneos e dispersos e têm atacado papel, mourões, troncos de árvores em construções de áreas rurais (Alves \& Berti Filho, 1995).

Heterotermes tenuis (Hagen) foi relatada por Araújo (1970), como uma espécie de ocorrência nas Antilhas, América Central e muitos países da América do Sul. E embora fosse uma espécie restrita a áreas agrícolas, foi observada atacando madeira manufaturada na Guatemala.

Heterotermes também foi constatada em três construções na cidade de São Paulo por Lelis (1994).

Procornitermes, normalmente não ocorre em residências, mas já foi visto atacando cabos telefônicos e elétricos, tubos de PVC e de alumínio, gesso, compensados e móveis (Alves \& Berti Filho, 1995).

Nasutitermes globiceps tem sido relatado como responsável por danos em mourões, postes, ranchos e paióis em áreas rurais (Alves \& Berti Filho, 1995). 
O cupim subterrâneo Reticulitermes lucifugus, segundo Aber \& Fontes (1993), embora ainda não assinalado no território brasileiro, pode ser introduzido através do Uruguai onde tem causado prejuizos consideráveis em áreas urbanas.

2.3. Como diferenciar os danos causados por cupins dos causados por outros insetos deterioradores de madeira

Além de existirem distintas formas de danos causados pelos diferentes tipos de cupins, existem outros insetos considerados xilófagos cujo ataque é freqüentemente confundido com $\circ$ ataque de cupins. Torna-se, portanto, necessário o conhecimento das caracteristicas que podem levar a identificação do agente causador do dano.

\subsubsection{Coleópteros ou brocas de madeira}

Os coleópteros fazem furos ovais ou redondos na superfície da madeira para a saída do inseto já adulto. Apenas a fase larval do coleóptero vive e se alimenta no interior de peças de madeira e o resíduo lançado é um pó fino, sendo esta uma forma simples de diferenciar o seu ataque do dos cupins de madeira seca ou de madeira úmida (Edwards \& Mill, 1986).

De acordo com Milano (1998), os ataques de brocas mais freqüentemente confundidos com o ataque de cupins são os causados por Lictídeos e Anobiídeos. Os Lictídios são caracterizados por abrirem orifícios circulares com 2 a 3 milimetros de diâmetro, o resíduo que lançam para fora da peça atacada é um pó semelhante a talco, depositado em forma de montículo logo abaixo do orifício. Os Anobiídeos fazem orifícios com 3 a 4 milimetros de diâmetro e 0 resíduo que lançam para o exterior da peça atacada é de textura levemente granulada. 


\subsubsection{Formigas carpinteiras}

As formigas carpinteiras, segundo Edwards \& Mill (1986), são espécies do gênero Camponotus que constróem seus ninhos dentro da madeira mas não se alimentam dela. O seu ataque dá à madeira uma superfície laminada, pois as operárias removem o lenho inicial e preservam o tardio. Abrem muitos túneis, paralelos à grã da madeira e jogam os resíduos para fora da peça, dando aos túneis aspecto limpo.

\subsection{Fatores que propiciam ou que mantém as infestações por cupins nas construções urbanas}

\subsubsection{Uso de madeiras pouco resistentes e sem tratamento}

Spear (1970) considera que madeiras resistentes são impalatáveis ou repelentes aos cupins. Sendo assim, madeiras que não possuem estas características devem ser evitadas em regiōes de altos índices de infestações e se forem utilizadas, é aconselhável que passem por tratamento com produtos especiais que evitem que esta madeira seja atacada. A maior vantagem apresentada pela madeira preservada é a maior durabilidade em serviço o que aumenta 0 intervalo entre as substituições, diminuindo os custos com manutenção da edificação.

Deve-se ressaltar que as madeiras que possuem resistência natural aos cupins são geralmente caras, pouco disponiveis no mercado e, segundo Edwards \& Mill (1986), nem todas são completamente imunes a esses insetos.

Segundo Santini (1988), existem várias metodologias já consolidadas para o tratamento de preservação de madeiras que levam em consideração o tipo de madeira e a sua finalidade. Os métodos mais simples não utilizam preșsão e são: pincelamento, aspersão, imersão simples, difusão, substituição da seiva, 
processo de Boucherie, banho quente-frio, injeção preservativa e impregnação de árvore em pé. Os métodos mais complexos, que utilizam pressão artificial para a impregnação do preservativo na madeira são: célula cheia (processo de Bethell, processo Brunett, processo Boulton e processo duplo vácuo) e célula vazia (processo Rüping e processo Lowry).

\subsubsection{Uso de técnicas construtivas inadequadas}

Entenda-se por técnicas construtivas adequadas, aquelas que em conjunto impeçam ou minimizem a infestação das edificações por cupins. Dentre estas técnicas estão a escolha dos materiais a serem utilizados na construção, que não devem conter celulose em sua composição ou, se tiverem devem ser devidamente tratados.

De acordo com Bonturi (1998) é mais econômico e mais simples utilizar-se metodologias que previnam infestações por cupins do que combater a infestação.

Para Brooks (1991), a madeira é um material de origem orgânica que deve ser utilizado quando se tem conhecimento de suas limitações. Para isso, foram criadas normas para a sua utilização. Tais normas definem classes de risco, de acordo com a severidade e o tipo de risco biológico a que a madeira será exposta quando em serviço. Estas normas, em conjunto com informações sobre a resistência natural da madeira a ser utilizada, vão definir a função na qual a madeira pode ser utilizada na construção, suas restrições, bem como irá fornecer dados para se decidir sobre a necessidade ou não de tratamento preservativo. O autor considera a implementação de normas para a utilização da madeira como imprescindível na realização de qualquer obra sob pena desta não estar cumprindo os requisitos construtivos adequados. 
Segundo Lelis (1999), a densidade e a proximidade das edificações em grandes cidades, como ocorre em São Paulo, facilitam a infestação por cupins subterrâneos, que estão presentes em árvores de praças e jardins e em grandes parques. O autor destaca a ausência de prevenção durante a execução das obras, onde é utilizada madeira não tratada nas formas para concreto e que são deixadas no interior das construções, ou a construção de pequenos espaços sem utilidade que são conhecidos como caixões perdidos. Muitas vezes esses espaços são preenchidos com entulho, incluindo restos de madeira, e depois são fechados Estes condições são consideradas favoráveis à instalação de ninhos de cupins nas proximidades ou interior destas edificações facilitando a sua dispersão para prédios vizinhos.

Hedges (1998) cita a umidade como fator determinante para a infestação por térmitas e que a construção de edificações pouco arejadas aumentam a quantidade de umidade facilitando e mantendo os cupins nestes locais.

Ainda com relação a umidade, Harris (1971), Hedges (1998) e Spear (1970) consideram que a não realização de drenagem do terreno antes do início das construções propiciam ambiente oportuno para o estabelecimento de cupins. subterrâneos.

A adoção de técnicas construtivas inadequadas, como o uso de telhas muito porosas, calhas entupidas ou subdimensionadas que provoquem vazamentos para o interior da edificação e molhem peças de madeira são determinantes para que ocorra a instalação de ninhos de cupins, principalmente os de madeira seca (Bareia, S.d.)

Alves \& Berti Filho (1995) e Bareia (S.d.) aconselham evitar-se que peças de madeira tenham contato direto com a alvenaria ou com o solo, pois a 
madeira absorve a umidade dos mesmos, avariando principalmente as extremidades das peças e atraindo cupins.

Peças de madeira em contato com o solo atraem cupins subterrâneos porque, segundo Reinhard et al. (1997), os operários são capazes de detectar a madeira a partir de emanações de substâncias voláteis pelo solo e pelo ar. Essas emanações são seguidas e direcionam a construção dos túneis de forrageamento.

É necessário remover do terreno e da edificação, após a execução da obra, o entulho e principalmente os materiais lignocelulósicos descartados, evitando que estes atraiam os cupins de áreas próximas (Edwards \& Mill,1986; Fontes, 1995a; Lelis, 1999 e Spear, 1970).

Alves \& Berti Filho (1995) e Lepage et al. (1986) consideram que as madeiras de que são feitas as formas de concreto das edificações e que são deixadas no interior das mesmas, tornam-se fontes de alimento e atraem os cupins subterrâneos. Os autores recomendam que seja feito o tratamento ou a retirada destas formas, visto que são feitas de madeiras moles.

Segundo Fontes (1995a), o desconhecimento do potencial destrutivo dos cupins aliado a adoção de práticas construtivas inadequadas, contribuem para que seja disseminada e mantida a infestação por térmitas nas áreas urbanas. Segundo o autor, o problema relacionado ás práticas construtivas é complexo devido ao custo elevado das medidas e dos materiais necessários para a sua implementação, e deixa claro que os prejuizos causados pelos cupins superam os custos das medidas preventivas. 


\subsubsection{Falta de cuidados com a arborização urbana}

O mau planejamento e manejo das árvores do meio urbano, principalmente das grandes cidades, equivoco na escolha das espécies, no espaçamento, cuidados com podas e manutenção da sanidade, são fatores importantes para a perpetuação de infestações termíticas urbanas (Fontes, 1995a).

Fontes (1998) considera que a invasão da árvore pelo cupim subterrâneo se dá pelas raízes, tanto de árvores bem como de mal conduzidas e podem não mostrar sinais externos de ataque, mas podem ter o cerne destruído. Destas árvores os cupins podem passar a infestar edificações, re-infestar edificações tratadas bem como as edificações infestadas podem provocar 0 ataque em árvores. $O$ autor ainda cita a ocorrência de infestações aéreas das árvores por casais formados após as revoadas.

Para Laera (1998), o planejamento da arborização, através da escolha de plantas adequadas para as cidades e substituição de espécies erroneamente plantadas são soluções para se minimizar os prejuízos causados pelos maus tratos pelas podas "radicais". A autora salienta que o diagnóstico e controle de infestações prolongam a vida de árvores que fazem parte da história de muitas cidades e chama a atenção para a importância do trabalho da mídia na divulgação do problema de infestações por cupins, o que contribuirá significativamente para a otimização do seu controle.

Os cupins subterrâneos quando atacam árvores vivas, têm preferência por coníferas e por folhosas de crescimento rápido. Nestes casos, é necessária a verificação da origem das formas aladas e a presença de túneis nas plantas próximas ás edificações (Myles, 1999). 


\subsubsection{Utilização inadequada de materiais à base de madeira}

Uma alternativa para substituir a madeira nas construções ou na indústria moveleira é a utilização de chapas e painéis de madeira, como compensados, aglomerados, chapas dura de fibra, MDF, OSB, entre outros. Alguns destes materiais são especialmente susceptiveis ao ataque de cupins por serem normalmente, produzidos com madeiras pouco resistentes. Diante deste fato, têm sido incorporados nas colas ou nas resinas que unem lâminas ou fibras destes materiais, produtos que os tornam menos atrativos para os cupins.

Smith \& Zungoli (1995) constataram que a infestação por térmitas associadas a utilização de chapa dura de fibra não é incomum. Os autores acreditam que os cupins são especialmente atraídos por este material.

Tratamentos contra cupins em compensados podem ser implementados pela adição de trióxido de arsênico na cola. (Dimri et al., 1995).

Um fator importante para a utilização dos compensados é a verificação da espessura das lâminas que os constituem, pois de acordo com Shukla \& Joshi (1992), compensados feitos com lâminas mais espessas são mais susceptiveis ao ataque de cupins do que aqueles constituídos de lâminas mais finas.

Para Hickin (1971), compensados colados com fenolformaldeído são mais resistentes a cupins do que os colados com uréia formaldeído. $O$ autor ainda cita que colas a base de polivinilacetato e acetato de celulose são mais atrativos para Cryptotermes brevis do que a própria madeira.

A escolha de diferentes tipos de resina pode influenciar no nivel de ataque de cupins. Imamura et al. (1986) encontrou maior ataque de térmitas em painéis com resina Isocianato (MDI), do que em painéis com Fenolformaldeido 
(PF) e Melamina Uréia Formaldeído (MUF). A resistência também aumenta com a quantidade de resina utilizada.

Beal (1979) conseguiu produzir aglomerados, chapas duras e compensados resistentes a Reticulitermes flavipes, $R$. virginicus, Coptotermes niger, Heterotermes tenuis e Cryptotermes brevis adicionando alguns inseticidas à cola destes produtos.

\subsubsection{Tratamentos curativos mal aplicados}

Para Fontes (1998), a avaliação da extensão da infestação e a identificação do agente infestante são medidas indispensáveis para evitar-se tomada de decisão equivocada sobre a proporção e o tipo de tratamento curativo a ser adotado. $O$ autor considera que o subdimensionamento do tratamento pode ocasionar o mascaramento de infestações por cupins subterrâneos e como conseqüência a dispersão destes cupins, e que o superdimensionamento do tratamento curativo pode ocasionar contaminações ambientais, além de ter um custo muito elevado.

Segundo Milano (1998), quando não são tomadas medidas de controle adequadas as infestações de cupins vão se alastrando. Para o autor, boas medidas de controle não apenas implicam na destruição dos insetos, mas também impedem que os cupins ocupem outras áreas. Para que isto seja possível, além de utilizar-se bons equipamentos é necessário que se tenha conhecimento sobre o uso dos mesmos e sobre o tipo de cupim que está sendo combatido através da realização de inspeções realmente bem feitas. 


\section{MATERIAL E MÉTODOS}

\subsection{Caracterização do local de estudo}

Este trabalho foi realizado no bairro São Dimas, em Piracicaba, São Paulo $\left(22^{\circ} 42^{\prime} 30^{\prime \prime} \mathrm{S}\right.$ de latitude e a $47^{\circ} 38^{\prime} 01^{\prime \prime} \mathrm{W}$ de longitude, com altitude de $554 \mathrm{~m}$ ) As temperatura máxima registrada foi de $37,5^{\circ} \mathrm{C}$ e a mínima de $18,0{ }^{\circ} \mathrm{C}$. Piracicaba é o 19ำ município do Estado de São Paulo em extensão territorial, com área total de $1.312,3 \mathrm{~km}^{2}$, dos quais $158,06 \mathrm{~km}^{2}$ são de área urbana. $\mathrm{Na}$ cidade há 74.759 imóveis residenciais e 6.907 imóveis comerciais (Centro de Informática do Campus Luiz de Queiroz - CIAGRI, 1999).

Para a realização da amostragem, foi selecionado o bairro São Dimas. A escolha foi feita a partir do mapa obtido por levantamento aerofotogramétrico digital (abairramento - escala 1: 17500), fornecido pela SEMUPLAN (Secretaria Municipal de Planejamento) da Prefeitura de Piracicaba, atualizado em dezembro de 1997. Os fatores que determinaram a escolha desse bairro foram: histórico anterior de presença de cupins; edificações de idades bastante variadas, tanto antigas quanto novas, de estilos e técnicas construtivas distintas, e estar próximo ao Campus da Escola Superior de Agricultura "Luiz de Queiroz", possibilitando rapidez e facilidade de acesso.

No bairro São Dimas, de acordo com a Prefeitura Municipal de Piracicaba, existem 2451 imóveis residenciais e 197 imóveis comerciais. 
Foram sorteadas, aleatoriamente, 10 quadras de um total de 107 (Figura 4). Em cada quadra foi feito um levantamento, que visou verificar o número de edificações existentes e para que fins eram utilizadas (residência ou comércio). Desse levantamento, foram definidos os estratos a serem estudados para facilitar a análise estatística dos resultados: edificações residenciais e comerciais.

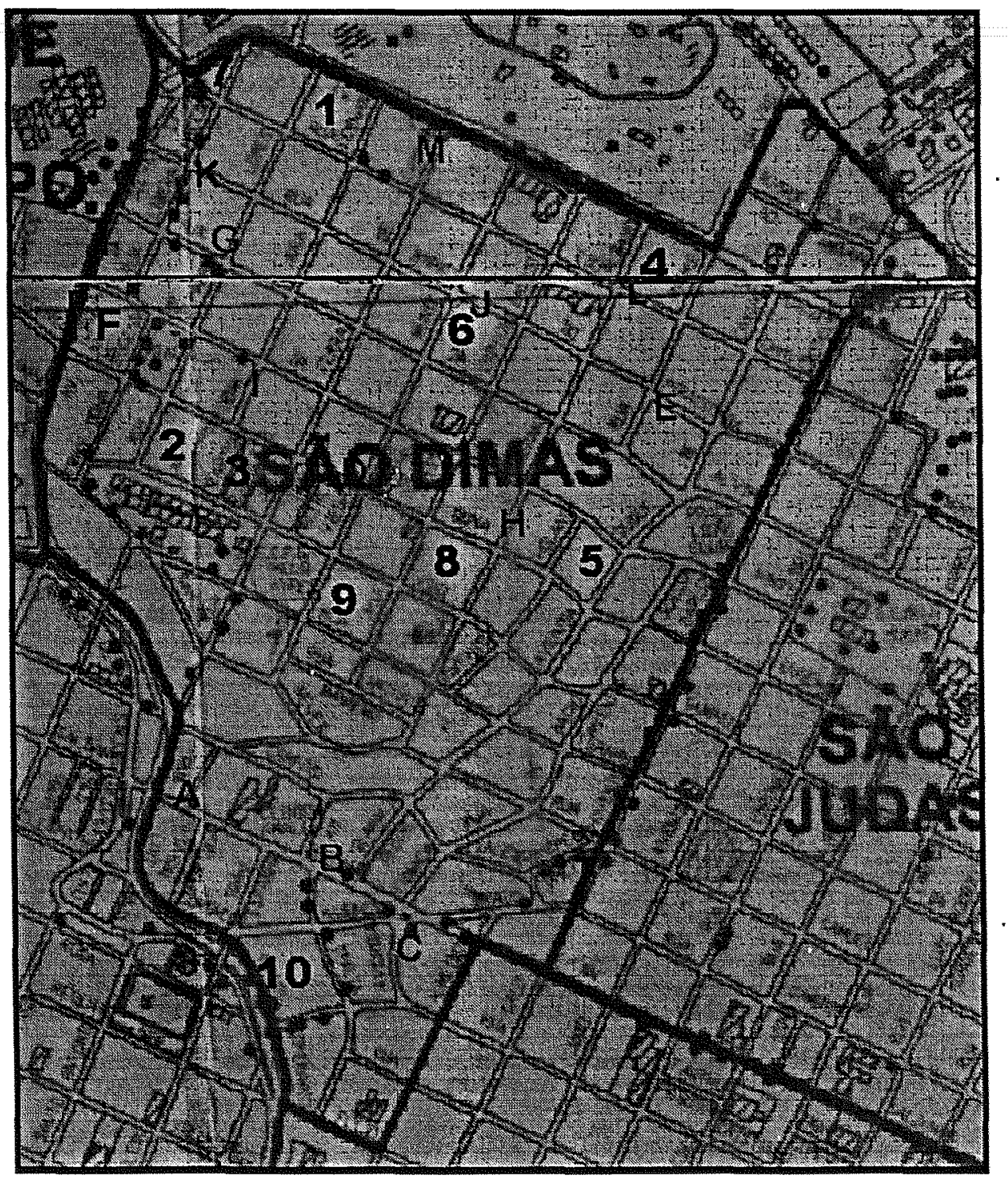

FIGURA 4. Mapa do bairro São Dimas, Piracicaba, SP, com as quadras sorteadas marcadas com números e localização dos prédios de apartamentos marcados com letras. 
Determinou-se o número de prédios de apartamentos existentes em todo o bairro Constantando-se que eram poucos, todos foram inspecionados e considerados como um estrato à parte.

Para a determinação de quais edificações residenciais seriam inspecionadas foi realizado um sorteio aleatório de 4 edificações por quadra.

Foi determinado, previamente às inspeções, que no caso de haver algum problema que impossibilitasse a visita a um dos imóveis sorteados, o próximo à sua direita o substituiria, e se este também não fosse possível de ser visitado, o próximo à esquerda do imóvel preferencial para a amostragem o substituiria e assim sucessivamente (Figura 5).

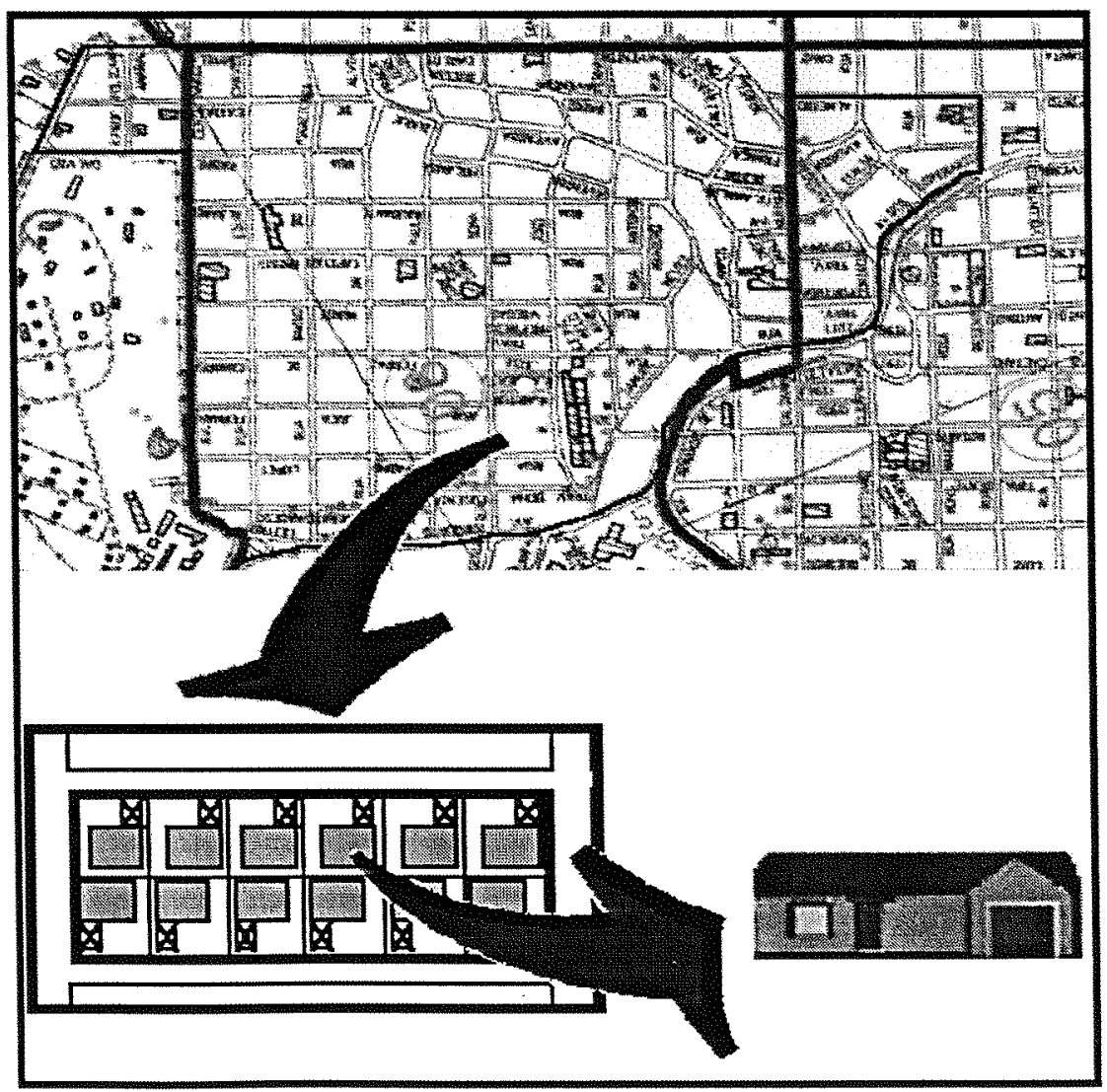

FIGURA 5. Esquema da amostragem: bairro, sorteio de quadras e sorteio de imóveis. 
Constatando-se, no levantamento da utilização dos imóveis nas quadras, que as edificações comerciais eram em pequeno número, todas foram consideradas na amostragem.

\subsection{Critérios para a inspeção das edificações}

As edificações foram examinadas quanto aos aspectos: presença de cupins nos diversos componentes da edificação, tipo de material utilizado na construção, espécie de madeira atacada (quando possivel foram retiradas amostras), tipo de material atacado (painéis a base de madeira ou produtos com celulose na sua composição), ocorrência de umidade nos diversos componentes da edificação e idade.

Os móveis foram inspecionados quanto aos aspectos: material utilizado na sua fabricação, condições de umidade do local onde estavam colocados e idade.

\subsubsection{Prédios de apartamentos}

Estavam previstas visitas a alguns apartamentos de cada prédio, que foram sorteados da seguinte forma: um apartamento no primeiro andar (primeiro piso), um no último andar e outro entre os andares que restaram. Em decorrência de não terem sido obtidas as autorizações dos moradores para a realização de inspeção nos seus apartamentos, as inspeções nos prédios de apartamentos foram conduzidas apenas nas áreas comuns.

Nos prédios de apartamentos foram verificadas, minuciosamente, quanto aos critérios descritos no item 3.2., as seguintes partes:

-subsolo - alguns prédios possuíam mais de um "subsolo" e os exames foram iniciados a partir do subsolo inferior. Foram verificados: casas de 
bombas, salas dos quadros de medição, juntas de dilatação, aberturas para passagem de eletrodutos e cabos telefônicos, bocas de lobo, aberturas das tubulações para o escoamento de excesso de água, aberturas para o sistema de esgoto, poços dos elevadores, salas para utensílios de materiais de manutenção e salas de depósitos dos condôminos.

- térreo - no térreo dos prédios de apartamentos estão localizados, a recepção, salão de festas e de jogos, sauna, piscina, banheiros e cozinhas coletivos. No térreo foram verificados: piso, forro e balcões, bem como mobiliário, pilares e portas. Na piscina foi verificada a casa de bombas dos filtros e eventual local para depósito de materiais. Além da parte interna da edificação, foram examinados também os jardins.

- cobertura - é na cobertura que está localizada a caixa de água e a casa de máquinas dos elevadores. Como já foram citados casos de infestações aéreas de cupins subterrâneos houve necessidade de examinar essas áreas. Nelas foram verificadas: caixas d'água e adjacências, casa de máquinas dos elevadores, eventuais espaços sem utilização.

Todas as inspeções foram acompanhadas por um responsável designado pelo síndico do prédio, que era conhecedor das instalações do prédio.

\subsubsection{Prédios residenciais}

Após realizado o sorteio das edificações, foi realizado um primeiro contato com o morador, ocasião em que foi discutido o problema e entregue um ofício com o pedido de permissão para a realização da inspeção.

A edificação foi observada de acordo com os critérios pré-estabelecidos anteriormente (item 3.2), onde foram verificadas as seguintes partes: 
-porão - na existência de porão foi verificado todo o seu interior, móveis portas e janelas.

-parte interna - foram verificadas todas as janelas e portas, forro, piso, rodapés, paredes e móveis.

-parte externa - verificou-se o jardim e árvores dentro e fora do muro da edificação, ou seja, árvores localizadas nas calçadas próximas a edificação também foram analisadas. Edículas, lavanderias e varandas foram igualmente inspecionadas.

Quando constatada severa infestação em forros de madeira, foi utilizado um resistógrafo para testar as peças estruturais do telhado em contato com o forro, visando avaliar o grau de comprometimento das mesmas para evitar riscos ao morador e auxiliar na solução do problema.

\subsubsection{Prédios comerciais}

Os prédios comerciais foram inspecionados segundo os mesmos critérios utilizados para os prédios residenciais. Foi dada, no entanto, atenção especial aos materiais utilizados na divisão de cômodos (divisórias e móveis) e que não existiam em prédios residenciais.

\subsection{Condução das inspeções}

Nas inspeções foram procuradas evidências da presença de cupins subterrâneos e/ou de madeira seca.

Para diferenciar as infestações pelos diversos organismos xilófagos foram seguidas as seguintes características (Antonelli et al., 1996): 
- fungos - madeira sem a presença de galerias, câmaras ou túneis; presença de fissuras nas peças de madeira; peso reduzido; madeira desfiandose, tornando-se uma massa amolecida ou virando pó.

- brocas - Anobiídeos (presença de galerias, câmaras e/ou túneis na madeira; pequenos orifícios de saída - 1 a $2 \mathrm{~mm}$; presença de pó de madeira e residuos fecais muito pequenos, granulares; normalmente em madeira de coníferas, principalmente úmidas); Lictídeos (presença de galerias, câmaras e/ou túneis na madeira; orifícios de saída maiores - 4 a $6 \mathrm{~mm}$; algumas vezes ovais; com túneis revestidos com pó ou fibras da madeira; residuos fecais menores do que os dos anobiídeos parecendo pó de serra; freqüentes em madeiras pesadas e secas); Buprestídeos (túneis planos na madeira, orifício de saída oval, 4 vezes mais largo do que alto, com molde em arco; presença de resíduos fecais nas galerias); Cerambicídeos (túneis longos e estreitos; orifícios de saída mais ou menos circulares; com galerias semelhantes as dos buprestídeos, mas sem o molde em arco.

- Formigas carpinteiras - presença de galerias, câmaras e túneis na madeira; escavações muito lisas e limpas; sem residuos fecais; com um pouco de pó ou fragmentos de madeira depositados em pilhas distintas;

- Cupins subterrâneos - presença de galerias, câmaras e túneis na madeira; escavações contendo massa de partículas de solo; partículas ou pó da madeira retirada salpicando as paredes das galerias; sem resíduos fecais; tubos de terra na parte externa da madeira ou das fundações;

- Cupins de madeira seca - presença de galerias, câmaras e túneis na madeira; com resíduos fecais mais longos do que largos; com sulcos longitudinais; 
- Cupins de madeira úmida - presença de galerias, câmaras e túneis na madeira; com resíduos fecais duas vezes mais longos do que largos, sem sulcos longitudinais.

\subsubsection{Cupins subterrâneos}

A presença de galerias, que os cupins subterrâneos constróem para se deslocar pela construção, foi considerada o principal indicio de sua presença. Em locais escuros, tais evidências foram procuradas com o auxílio de lanterna, para melhor visualização dos locais menos acessiveis (porões e locais sem utilização constante), e de peças sob suspeita. Pinça anatômica e chave de fenda foram empregadas para testar a presença de galerias internas em.peças de madeira e para abrir pequenos vãos entre juntas de dilatação para a verificação da presença de trilhas de forrageamento. Ao constatar a infestação por cupins subterrâneos, o local onde foram localizados os indícios de sua presença foi inspecionado com maior rigor, a fim de coletar o cupim infestante para identificação, e obtenção de amostras do material atacado .

Os dados foram anotados em fichas individuais, para imóvel e móveis, para posterior agrupamento e análise.

\subsubsection{Cupins de madeira seca e de madeira úmida}

As observações foram direcionadas para: a presença de orifícios na superfície de peças e estruturas de madeira e móveis e localização de grânulos fecais, os quais são eliminados para fora da madeira pelos cupins para a desobstrução de suas galerias. Mesmo em locais de claridade razoável foi utilizada uma lanterna para visualização mais clara da peça. Pinça e chave de fenda foram utilizadas para testar a presença de galerias internas nos batentes de portas e janelas e outras peças, no caso de terem sido verificados 
previamente sinais da presença desses cupins (grânulos fecais e/ou orifícios). Foram coletados, quando possível, cupins que infestavam estruturas de madeira (soldados e operários) e colocados em recipientes com álcool a $70 \%$. Quando não foi possivel encontrar os cupins coletou-se os grânulos fecais. Estas amostras foram utilizadas para a identificação do agente causador da infestação.

Os dados foram anotados em fichas individuais, para imóvel e móveis para posterior agrupamento e análise.

\subsection{Identificação do agente causador do ataque}

A identificação dos cupins foi realizada no Departamento de Entomologia, Fitopatologia e Zoologia Agrícola da ESALQ/USP, em Piracicaba, pelo Dr. Luiz Roberto Fontes.

Os cupins foram também observados em microscópio eletrônico de varredura de pressão variável (MEV LEO 435 VP) do NAP/MEPA (Núcleo de Apoio à Pesquisa em Microscopia Eletrônica Aplicada a Agricultura/ ESALQ/USP) em alto vácuo. Para tanto foram retirados do álcool a $70 \%$, secos ao ar por 15 minutos, dispostos em "stubs" sobre fita de carbono dupla face e metalizados por 180 segundos.

A análise dos grânulos fecais dos cupins foi realizada por microscopia eletrônica de varredura no NAP/MEPA, ESALQ/USP. Os grânulos fecais foram colocados em fita de carbono dupla face e metalizados por 180 segundos, logo após foram observados em microscópio de varredura em alto vácuo. Desta forma, pode-se identificar a família a qual pertencem os cupins causadores do ataque: cupins de madeira seca (Kalotermitidae) ou cupins de madeira úmida (Termopsidae). 
As espécies de madeiras amostradas foram identificadas no Laboratório de Anatomia do Departamento de Ciências Florestais da ESALQ/USP, em Piracicaba, a nível de espécie.

\subsection{Análise dos dados}

Os dados foram analisados quanto a ocorrência de cupins de madeira seca e seu percentual, em relação ao total de construções inspecionadas, bem como quanto a ocorrência de cupins subterrâneos e seu percentual, em relação ao total de construção inspecionadas, levando-se em conta as espécies de cupins encontradas, a ocorrência de cupins de madeira seca e subterrâneos simultaneamente. Procurou-se estabelecer correlação entre a ocorrência de cupins e a idade da construção, a proporção de madeira na construção.e nos móveis, o tipo de madeira (maciça ou reconstituida), a ocorrência de umidade na construção. E as partes da construção mais atacadas (telhado, rodapés, batentes etc). 


\title{
4. RESULTADOS E DISCUSSÃO
}

Os resultados, da mesma forma que a amostragem, são apresentados separados em três estratos: edificações residenciais, comerciais e prédios de apartamentos.

Os fatores que influenciam o ataque dos cupins são discutidos por estrato.

\subsection{Estrato 1-Residências}

\subsubsection{Edificação}

\subsubsection{Número de edificações com cupins e peças mais freqüentemente atacadas}

\begin{abstract}
Dentre as edificações residenciais, a madeira é utilizada preferencialmente em peças de acabamento, tais como aberturas internas (portas e suas guarnições), aberturas externas (portas e janelas e suas guarnições), rodapés e pisos.
\end{abstract}

A madeira apareceu como o material preferencial na construção da estrutura dos telhados e foi utilizada em menor escala na confecção dos beirais. Outros materiais além da madeira também foram bastante encontrados, principalmente em forros e beirais (alvenaria), pisos (cerâmica) e aberturas externas (alumínio ou aço). Todas as edificações apresentaram algum componente em madeira. 
Registrou-se (Tabela 1) a incidência de cupins nas diferentes partes da edificação. Nas edificações residenciais apenas foram encontrados focos de cupins de madeira seca.

Das 40 edificações analisadas, as aberturas externas de madeira estavam presentes em $35(87,5 \%)$ das edificações, sendo $10(25,0) \%$ atacadas por cupins de madeira seca (Figura 6).

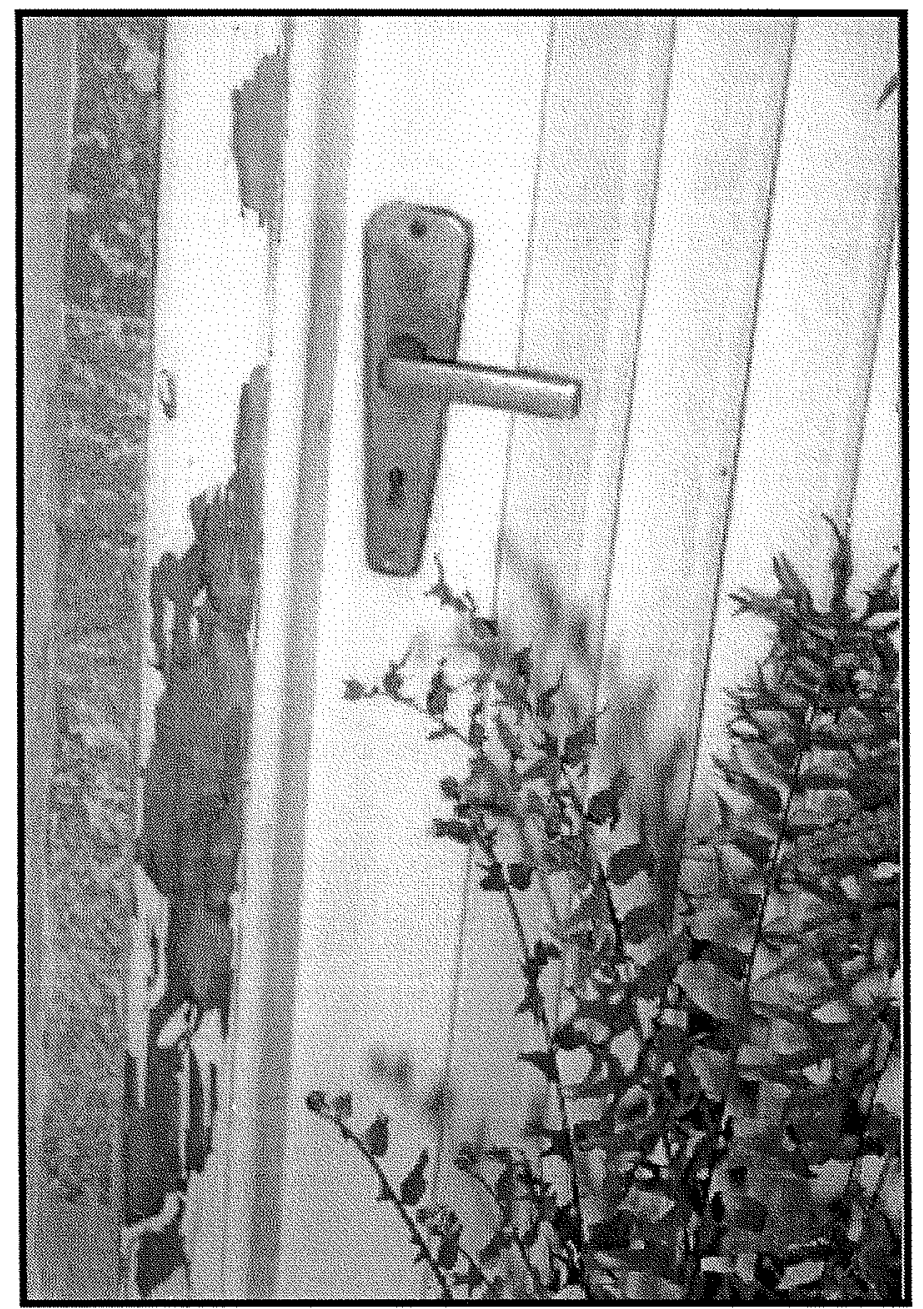

FIGURA 6. Guarnição de porta externa de edificação residencial atacada por cupins de madeira seca. 


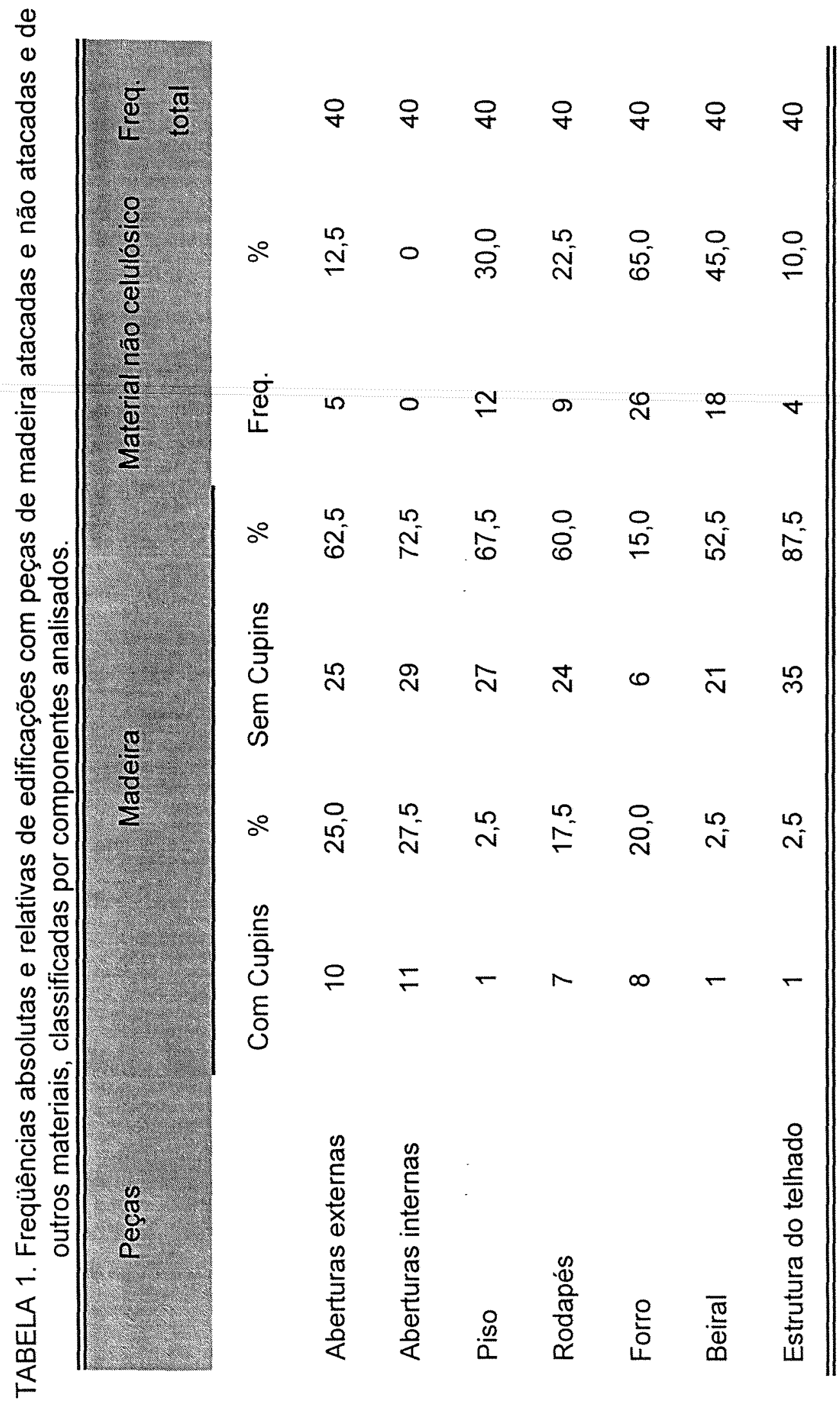


Um fator que pode influenciar o ataque por cupins é a exposição da peça às revoadas, assim, aberturas externas têm tendência a sofrer ataques com maior freqüência. Segundo Fontes (1998), o cupim de madeira seca Cryptotermes brevis, ataca apenas o madeiramento interno das edificações. Apesar disto, pode-se considerar que as peças que estão voltadas para a parte externa da edificação, que não estão expostas diretamente às intempéries, oferecem boas condições ao estabelecimento de cupins de madeira seca.

Todas as edificações apresentaram aberturas internas de madeira, sendo $11(27,5 \%)$ atacadas por cupins de madeira seca, contra $29(72,5 \%)$ não atacadas.

Houve maior freqüência de cupins em portas de banheiros. Um possível motivo para este fato é o constante umedecimento das mesmas, provenientes principalmente da evaporação da água dos chuveiros.

Dentre o total de edificações amostradas, $28(70,0 \%)$ possuem piso de madeira, contra $12(30,0 \%)$ de outros materiais. Foram encontrados cupins no piso de apenas 1 edificação (2,5\%). Este resultado pode ser atribuído a utilização de madeiras mais duras e resistentes para essa função, dificultando o ataque.

A maior parte dos rodapés das edificações amostradas são de madeira, totalizando $31(77,5 \%)$ contra $9(22,5 \%)$ de outros materiais. Dos rodapés de madeira foi verificado o ataque de cupins em apenas $7(17,5 \%)$.

Os rodapés, por serem utilizados como acabamento, sem função estrutural, são feitos de madeira menos resistentes e por isso são mais suscetiveis aos ataques de cupins do que os pisos. 
Foi observado nas edificações amostradas, que 14 (35,0\%) possuem forros de madeira, contra $26(65,0) \%$ de outros materiais. Dentre os forros de madeira foram encontrados cupins de madeira seca em $8(20,0 \%)$ (Figura 7 ).

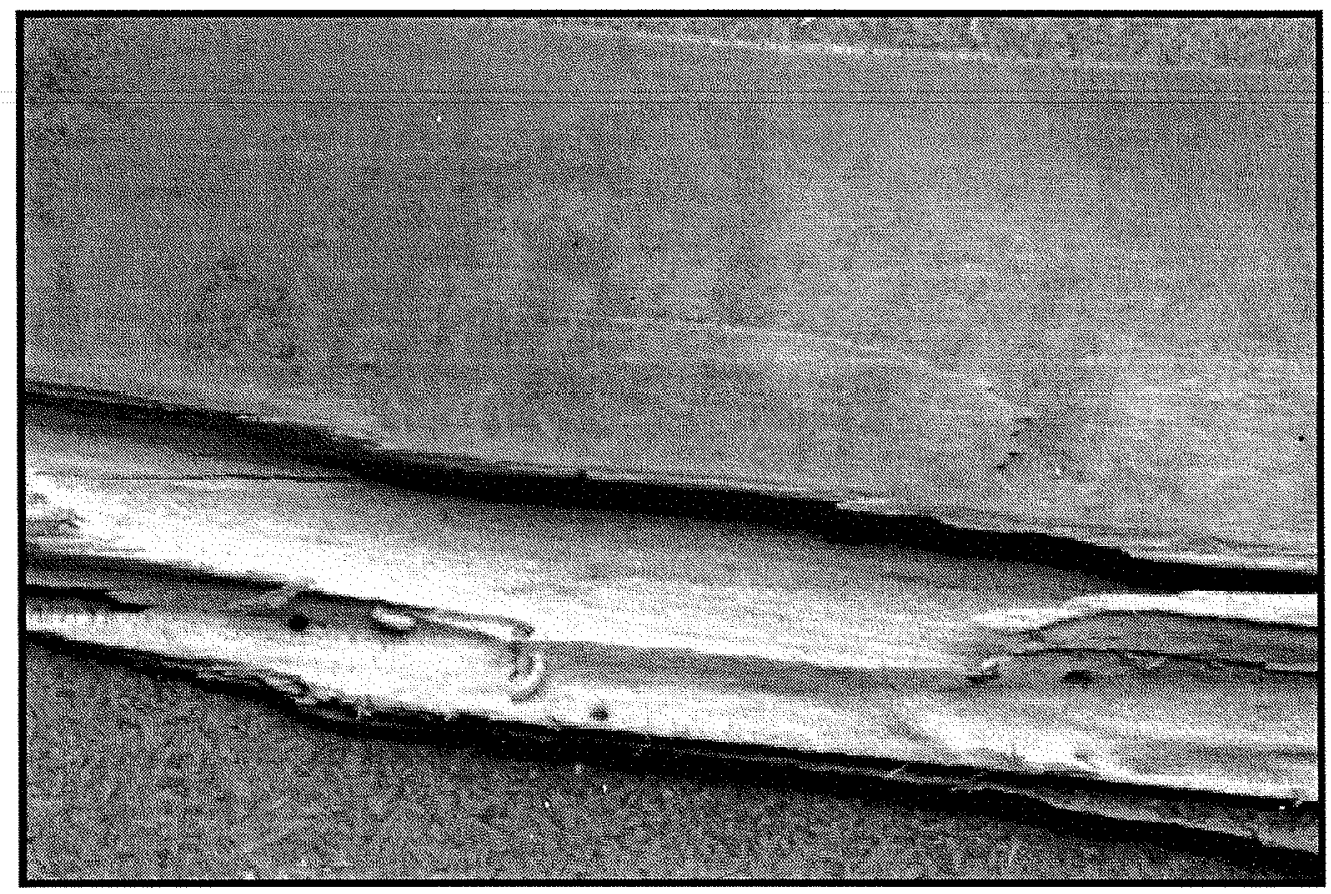

FIGURA 7. Peça de forro atacado por cupins de madeira seca.

Dentre as edificações cujos forros são de madeira, a freqüência de ataque de cupins foi alta, aproximando-se de $60,0 \%$.

O alto percentual de ataque do madeiramento do forro pode ser influenciado pelo modo de dispersão do cupim. Quando em revoada este inseto é atraído pela luz, localizada no forro que, sendo de madeiras suscetíveis, facilita $o$ ataque. 
Dentre as edificações visitadas, $22(55,0 \%)$ possuem beirais de madeira, contra $18(45,0 \%)$ de outros materiais. Foi observado ataque de cupim no beiral de apenas 1 edificação $(2,5 \%)$.

Dentre as 40 edificações visitadas, $36(90,0 \%)$ possuem estrutura do telhado de madeira, contra $4(10,0 \%)$ de outros materiais. Das 36 edificações com telhados de madeira, em apenas $1(2,5 \%)$ foi constatado o ataque, por cupins de madeira seca. Dois fatores que podem influenciar a baixa infestação de cupins na estrutura de telhados são, a sua construção com madeiras duras e resistentes e a proteção do ataque de alados.

Ao examinar-se o madeiramento do telhado de uma construção com um resistógrafo, que indica a resistência da madeira à penetração de uma broca, observou-se que apesar do ataque severo ao forro, o madeiramento do telhado não foi atingido (Figura 8).

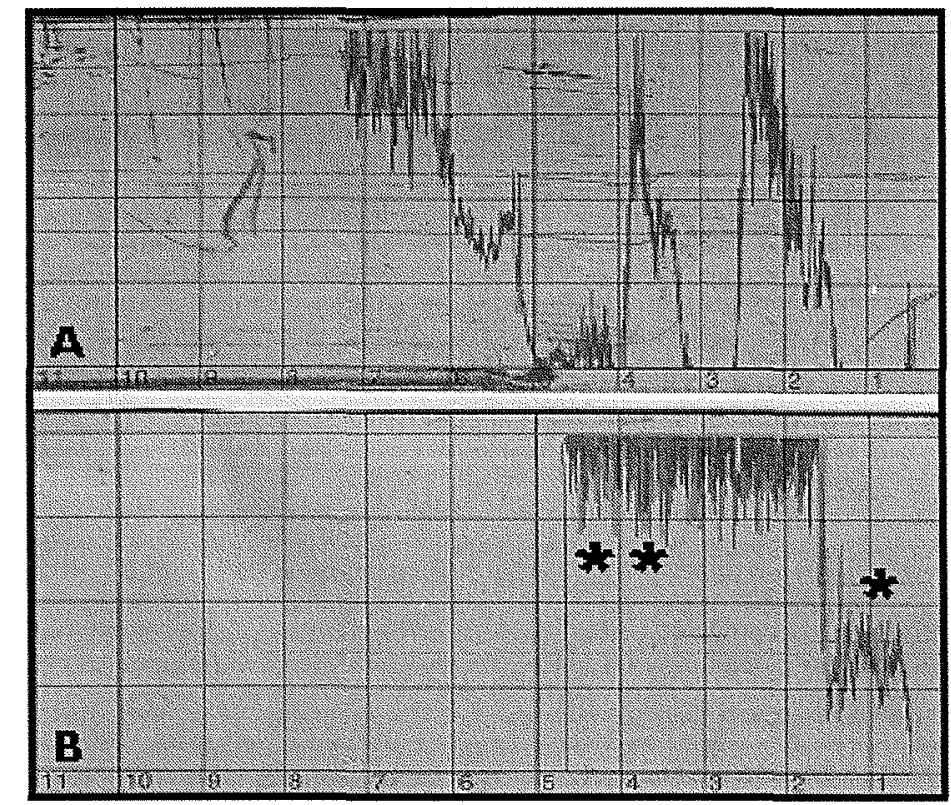

* forro, severamente atacado por cupins

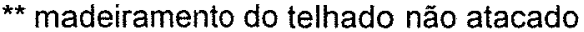

FIGURA 8. (A) madeira de uma janela atacada por cupins, as quedas mostram as galerias dos cupins de madeira seca. (B) madeiramento de forro e de telhado. 
Deve ser considerado, ainda, o fato de já existir alguma peça infestada no interior do imóvel, e que os alados, ao partirem desse foco, têm acesso direto ao madeiramento interno da edificação.

É importante salientar, que no bairro São Dimas, não há tradição em se utilizar qualquer tipo de tratamento preservativo contra ataque de cupins em madeiras suscetíveis ao empregá-las nas edificações. O uso destas madeiras é bastante difundido por serem tradicionais e com propriedades físicas e mecânicas condizentes com o uso, embora careçam de maior resistência à biodeterioração. A prática de utilizar madeiras não resistentes sem tratamento não é exclusividade dos construtores de Piracicaba, pois já foi constatada por Alves \& Berti Filho (1995), Lelis (1999) e Lepage et al. (1986), em outras cidades do Estado de São Paulo.

\subsubsection{Presença de cupins e idades das edificações}

As idades das edificações visitadas, variaram entre 0 e 90 anos, sendo que $47,5 \%$ estavam entre 15 e 30 anos. Estes resultados demonstram a variabilidade de idades dentro do bairro, o que influenciou a sua escolha para a realização deste trabalho.

Verificou-se (Tabela 2) que há uma tendência em aumentar a probabilidade de infestações por cupins com a idade da edificação. Em edificações novas, de 0 a 15 anos, nenhuma apresentou ataque por cupins, em edificações de 15 a 30 anos, 36,8\% apresentaram cupins e em edificações entre 30 a 45 anos, $75,0 \%$ apresentaram cupins. Nas faixas restantes de idade, de 45 a 60 anos, de 60 a 75 anos e de 75 a 90 anos todos os imóveis apresentaram cupins em alguma parte da sua construção. Comparando estes resultados pelo teste de $\chi^{2}$, encontrou-se que as diferenças são significativas. 
TABELA 2. Distribuição das freqüências absolutas e relativas das ocorrências de cupins em edificações residenciais agrupadas em classes de idades. A (porcentagem dentro da classe) e B (porcentagem sobre o total de residências amostradas).

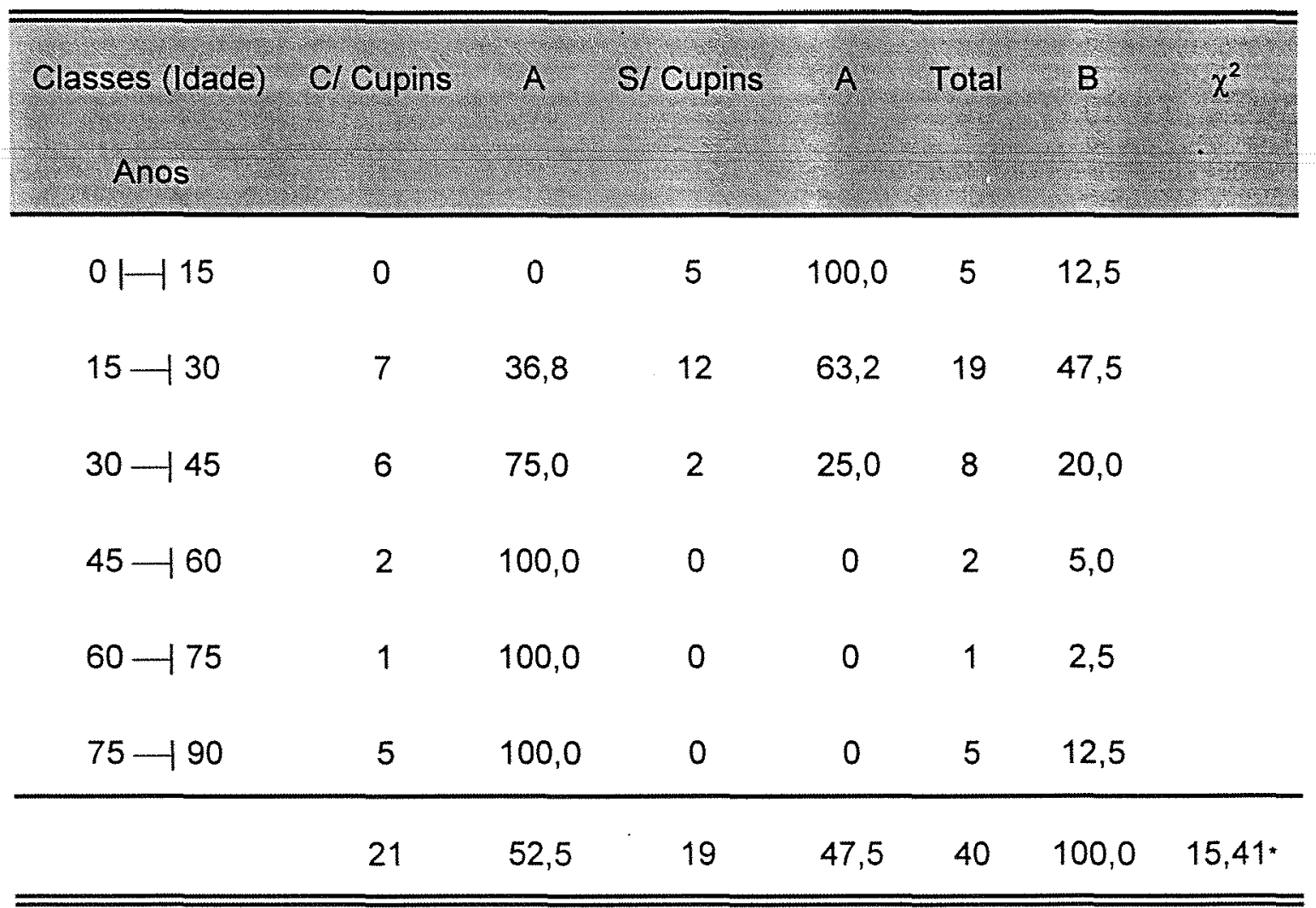

${ }^{* *} g l .=5 ; \alpha=1 \%$

O aumento na probabilidade de ataque de cupins com a idade das casas pode ser resultado do maior período de exposição dessas edificações às revoadas. Gold et al. (1996) constataram, estudando ocorrência de cupins em áreas costeiras do Texas, que em estruturas de mais de 40 anos de idade a probabilidade de infestação por uma ou mais espécies de cupins é superior a $90 \%$. 
Também pode-se considerar 0 desgaste e a falta de manutenção das edificações, como fatores que contribuem para $\circ$ estabelecimento de infestações de cupins., como umidade, por exemplo.

\subsubsection{Número de focos e idade das edificações}

O número total de edificações residenciais com ocorrências de cupins é 21 , sendo que uma edificação pode apresentar mais de um foco de cupins. Foi feita a análise da relação entre a idade da edificação e o número de focos de cupins por edificação (Figura 9).

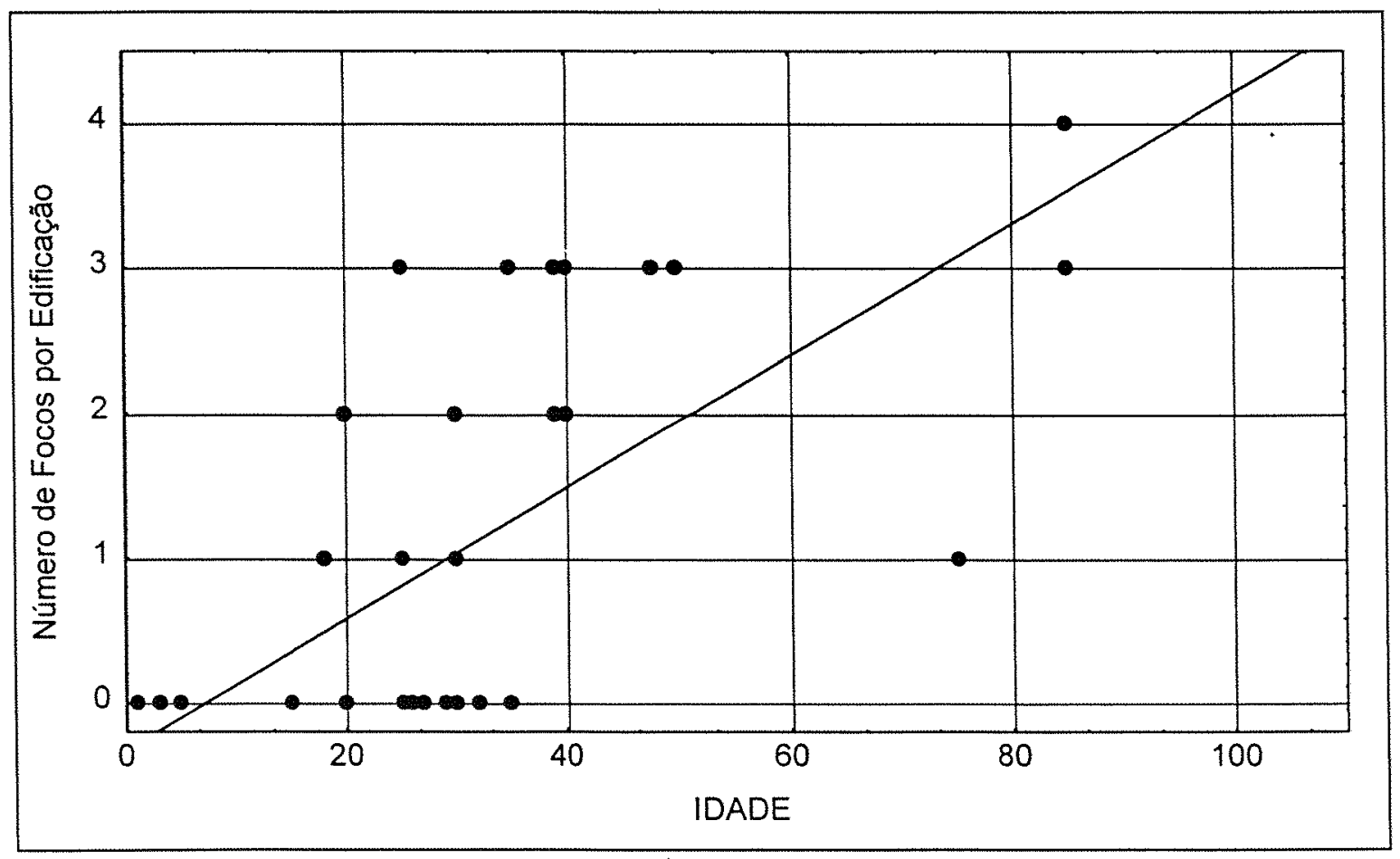

FIGURA 9. Relação entre idade das edificações e número de focos de cupins por imóvel. 
A correlação entre o número de focos e a idade das edificações, expressa pelo coeficiente de correlação de Pearson, é de $67 \%$. No entanto, deve ser considerada a existência de outros fatores que também influenciam no estabelecimento das colônias e que não foram mensurados neste estudo.

\subsubsection{Número de focos de cupins e tipos de materiais atacados}

Os resultados apresentados a seguir são referentes ao número total de focos de cupins nas edificações. Nas 21 edificações foram encontrados 54 focos de cupins. Destes, $40(74,1 \%)$ ocorreram em madeira maciça e 14 $(25,9 \%)$, estavam em sarrafeados.

Deve-se considerar o fato de que a madeira maciça foi o material mais utilizado para peças de acabamento das construções. Isto se deve à tradição e à disponibilidade de madeiras maciças no mercado. No Brasil, ao contrário de outros países, utiliza-se pouco painéis de madeira na construção de edificações. Considerou-se, então, que os painéis foram menos atacados por serem menos utilizados, visto que são tão suscetíveis aos cupins quanto a madeira maciça, pois são feitos de madeiras moles e pouco resistentes.

Após serem atraídos pela iluminação da edificação, o ataque de cupins às portas internas pode ser devido ao tipo de material utilizado, normalmente compensado ou madeira mole, que são sarrafeados internamente propiciando ao alado facilidade de acesso pelos espaços entre os sarrafos, bem como alimento farto. 


\subsubsection{Relação entre ocorrência de cupins e umidade}

É importante destacar que o conceito de umidade, considerado para este estudo, é subjetivo e foi um conceito médio que agrupou os diferentes focos em cada edificação.

Pode-se observar (Tabela 3) que a ocorrência de cupins de madeira seca foi maior em edificações que apresentam maior quantidade de umidade, sendo que quando há nenhuma ou pouca umidade as freqüências de infestações por cupins são menores, com $23,1 \%$ e $38,5 \%$, respectivamente. Quando a quantidade de umidade é grande, observou-se um aumento na freqüência de ataque, que foi de $92,8 \%$, contra $7,2 \%$ de não ocorrência de cupins. Estes resultados foram comparados pelo teste de $\chi^{2}$, e as diferenças encontradas são significativas.

TABELA 3. Freqüências absolutas e relativas de cupins em diferentes condições de umidade em edificações residenciais.

\begin{tabular}{ccccccc}
\hline \hline Umidade & Cl Cupins & $\%$ & Sl Cupins & $\%$ & Total & $\chi^{2}$ \\
\hline Nenhuma & 3 & 23,1 & 10 & 76,9 & 13 & \\
Pouca & 5 & 38,5 & 8 & 61,5 & 13 & \\
Muita & 13 & 92,8 & 1 & 7,2 & 14 & \\
\hline & 21 & 52,5 & 19 & 47,5 & 40 & $14,39^{\star *}$ \\
\hline \hline
\end{tabular}

$$
{ }^{* \star}(\mathrm{gl} .=2 ; \alpha=0,1 \%)
$$


Quando são considerados os cupins subterrâneos, os autores são unânimes ao considerar que altas umidades são favoráveis ao desenvolvimento das colônias e manutenção das atividades de forrageamento.

Segundo Hagsma \& Rust (1995), Hedges (1998), Howard et al. (1982) e Rudolph et al. (1990) o suprimento de água é, além da temperatura, o fator mais limitante, tanto ao estabelecimento, quanto à manutenção das colônias de cupins subterrâneos.

Quanto aos cupins de madeira seca, Edwards \& Mill (1986) e Rudolph et al. (1990) consideram que eles apresentam baixíssima exigência de água.

As informações da literatura são bastante conflitantes $e$, segundo os resultados deste trabalho, o fato de haver grande quantidade de umidade na madeira, parece favorecer o estabelecimento e desenvolvimento das colônias de cupins de madeira seca. Este resultado pode ser comparado com a afirmação de Bareia (S.d.) quando considera que peças de madeira que estejam úmidas facilitam a infestação por cupins, principalmente os de madeira seca.

Por outro lado, Waller \& La Fage (1986) consideram que a espécie Cryptotermes brevis prefere altas umidades quando precondicionada e que em temperaturas moderadas é capaz de tolerar uma faixa de umidade ampla. Os autores sugerem que a água se torna tóxica e é evitada pelos cupins quando em excesso na madeira, sendo que o controle se dá pela diminuição das atividades, do metabolismo, da temperatura do corpo e pelo progressivo armazenamento de gordura. No entanto, os autores consideram que este precondicionamento é um processo desconhecido.

Cabe ressaltar que, de acordo com Edwards \& Mill (1986), Noirot (1970), Rudolph et al. (1990) e Waller \& La Fage (1986), os cupins de madeira seca 
reutilizam a água do seu metabolismo, recuperando-a do material fecal, antes de elimina-lo, e que a umidade do ar é fonte indireta de umidade para colônia. Desta forma eles não necessitam de madeiras com altos teores de umidade. Pode ser considerado, então, que o aumento da freqüência de cupins de madeira seca, nas edificações que apresentam peças muito úmidas, independe da quantidade de umidade. Ou seja, colônias de cupins de madeira seca, devido ao seu metabolismo, podem se estabelecer ou se manter em peças com grandes quantidades de água, desde que a peça de madeira não esteja totalmente exposta aos fatores ambientais (sol e chuva).

\subsubsection{Móveis}

Dentre as 40 edificações visitadas, foram encontrados 28 móveis infestados por cupins de madeira seca, distribuídos em 18 edificações.

\subsubsection{Número de focos de cupins e tipos de materiais atacados}

Com relação ao material do qual eram feitos os móveis, pode-se verificar que $o$ atacado com maior freqüência foi a madeira maciça, com 16 casos $(57,2 \%)$, seguido do compensado, com 9 casos $(32,1 \%)$ e com menor freqüência, móveis de aglomerado, com 3 casos $(10,7 \%)$. Os móveis de madeira reconstituída, quando considerados juntos, compensado e aglomerado, foram menos atacados por cupins do que os de madeira maciça, com a freqüência de $42,8 \%$.

Quanto ao material dos móveis, pode-se observar que a madeira maciça é o material preferencial para a fabricação de móveis. Apesar disso, a utilização de painéis à base de madeira vem crescendo no mercado, sendo o aglomerado 
e o compensado os mais utilizados pela indústria moveleira. Neste trabalho foi observada baixa freqüência de cupins em aglomerados e compensados.

A freqüência de ataque de cupins aos compensados depende muito qualidade dos mesmos, onde são considerados a espessura das lâminas (Shukla \& Joshi, 1992); ao tipo e quantidade de cola utilizado (Imamura et al., 1986 e Forest Products Laboratory, 1999) e a adição ou não de inseticidas às suas linhas de cola (Beal, 1979).

Pode-se dizer que os casos de ataque aos aglomerados são mais raros devido ao processo pelo qual são produzidos. Os aglomerados se caracterizam pela cola recobrir toda a madeira e esta é, normalmente, impalatável aos cupins (Beal, 1979).

No entanto, segundo Forest Products Laboratory (1999), aglomerados com partículas grandes podem ser bastante atrativos aos cupins e se recomenda que, neste caso, seja utilizado algum tipo de inseticida na composição do painel. Além disso, a durabilidade de painéis à base de madeira depende do tipo de cola utilizada, sendo que a exposição constante a altas umidades e temperaturas provoca o decaimento da cola, deixando o material mais suscetível a biodeterioração. Atualmente têm se desenvolvido colas que resistem às intempéries e à biodeterioração por mais de 30 anos.

Devido ao pequeno número de amostras de móveis de diferentes materiais, não foi possível estabelecer uma relação clara entre a idade das peças e ocorrência de cupins.

\subsubsection{Análise conjunta das edificações e móveis}

Considerando-se todas as edificações inspecionadas, pode-se separá-las em três grupos: as que apresentem cupins tanto em peças da construção como 
em móveis, em número de $11(27,5 \%)$, as que apresentaram cupins apenas na edificação, em número de $10(25,0 \%)$ ou apenas nos móveis $7(17,5 \%)$ e as que não apresentaram focos de cupins, $19(47,5 \%)$.

Desta forma, a presença de cupins na edificação não implica, necessariamente, em infestação dos móveis e vice-versa. Possivelmente este resultado é devido às diferentes características existentes entre os móveis e os imóveis. Dentre elas pode-se citar, tipo de material, tipo de acabamento (pintura) e diferentes condições de umidade, entre outros.

\subsubsection{Arborização}

Constatou-se que as edificações residenciais do bairro estudado são pouco arborizadas, sendo que em grande parte possuem quintal cimentado ou pavimentado com cerâmica. Desta forma, verificou-se que 17 edificações $(42,5 \%)$ não possuem jardins ou árvores, contra $23(57,5 \%)$ que possuem um ou outro. Destas, em apenas 1 planta foram encontrados cupins (2,5\%) (Figura 10)

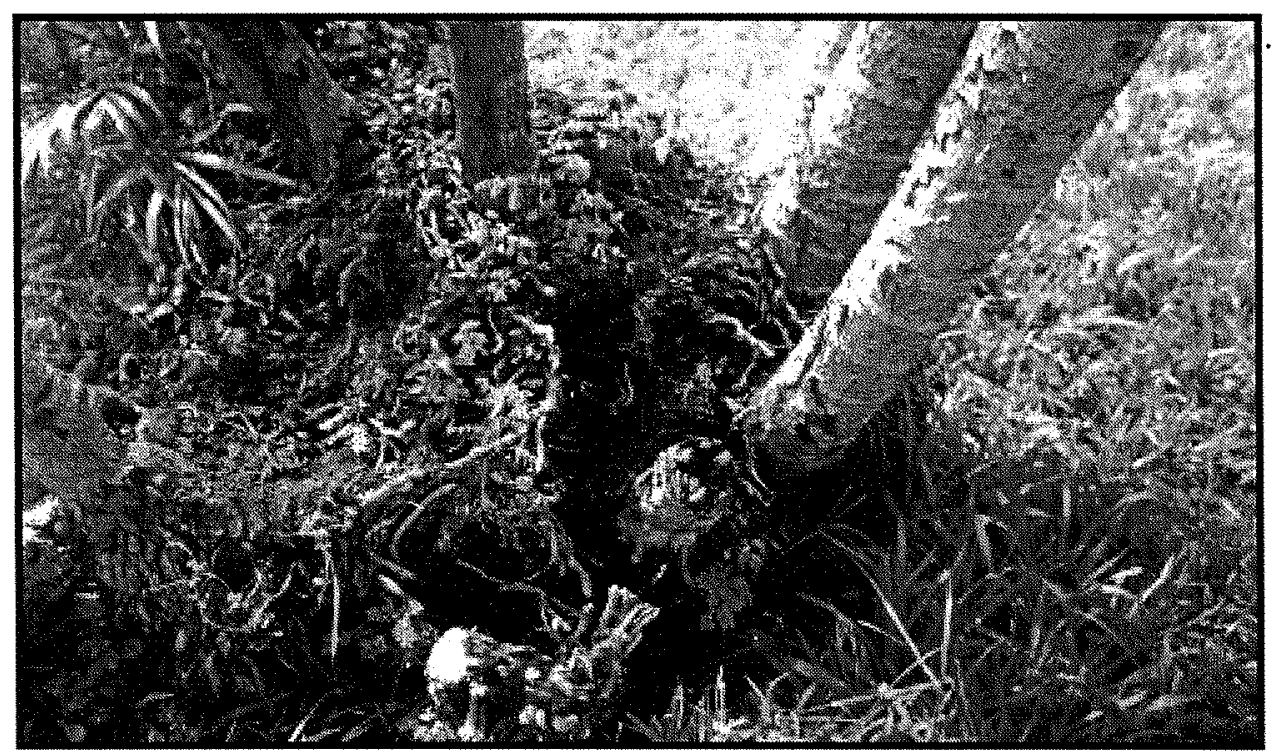

FIGURA 10. Planta de uma edificação residencial que apresentou cupins Embiratermes sp. 
Pode-se verificar, através dos resultados expostos no item anterior, que o fato da maior parte das edificações residenciais não possuir jardins ou arborização, não significa necessariamente que as edificações não estejam infestadas por cupins.

Além disso, foi verificado dentre a arborização existente, que as plantas foram bem escolhidas e não necessitam de podas radicais para evitar que batam na fiação elétrica e também que são bem cuidadas e saudáveis o que, segundo Fontes (1995a), são condições imprescindíveis para se evitar a instalação e a perpetuação de infestações por cupins em áreas urbanas.

\subsection{Estrato 2-Comerciais}

\subsubsection{Edificação}

\subsubsection{Número de edificações com cupins e suas peças mais freqüentemente atacadas}

A madeira demonstrou ser o material preferencial na construção da estrutura dos telhados e beirais e foi utilizada em menor escala na confecção dos pisos e rodapés. Outros materiais além da madeira também foram bastante encontrados, principalmente em forros (alvenaria), pisos (cerâmica) e aberturas externas (alumínio ou aço). Destaca-se, no entanto, que todas as edificações apresentaram algum componente em madeira.

Dentre as edificações comerciais, a madeira é um material também bastante utilizado para a construção das aberturas internas (portas e suas guarnições), das aberturas externas (portas, janelas e suas guarnições). Diferente do ocorrido em residências, nas edificações comerciais não utiliza-se 
madeira na confecção de pisos e de rodapés, sendo que estes são feitos de cerâmica.

Anotou-se (Tabela 4) a incidência de cupins nas diferentes partes da edificação. Nas edificações comerciais apenas foram encontrados focos de cupins de madeira seca. 
TABELA 4. Freqüências absolutas e relativas de edificações com peças de madeira atacadas e não atacadas e de outros materiais, classificadas por componentes analisados.

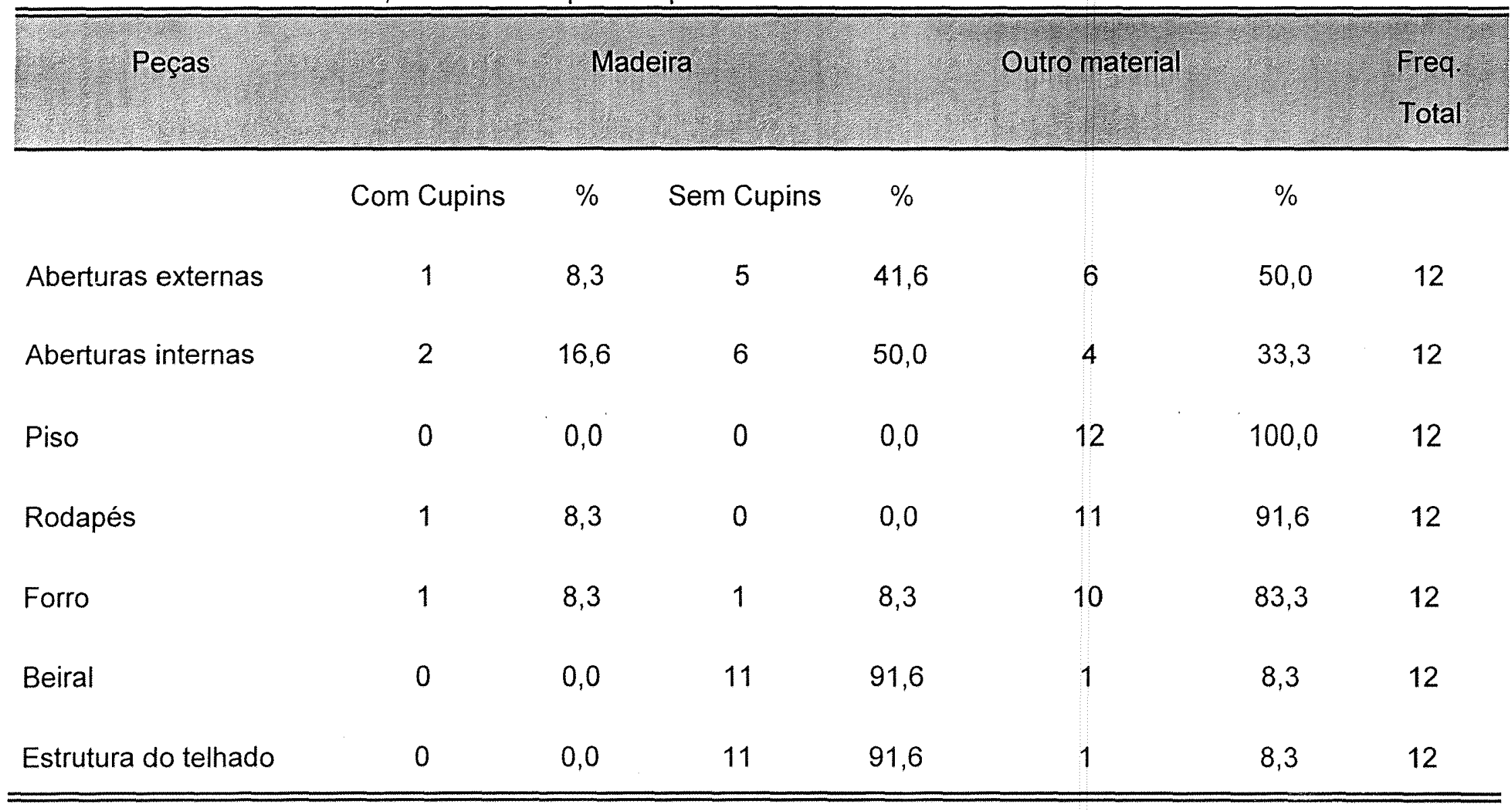


Foi observado que as peças mais atacadas por cupins em edificações comerciais foram as aberturas internas (portas, marcos e guarnições). Das 12 edificações analisadas, $8(66,6 \%)$ possuem aberturas internas de madeira, sendo que $2(16,6 \%)$ apresentaram cupins de madeira seca (em portas de banheiros), contra $6(50,0 \%)$ que não apresentaram cupins.

Em edificações comerciais os chuveiros raramente são utilizados, portanto, não há umedecimento das portas dos banheiros, o que pode explicar a menor ocorrência de cupins de madeira seca nas portas dos mesmos, em comparação com o que foi constatado em edificações residenciais.

Também pode ser considerado o material das portas, que possivelmente é de baixa resistência a biodeterioração.

Das 12 edificações visitadas, $6(50,0 \%)$ têm aberturas externas de madeira, dentre as quais apenas $1(8,3 \%)$ apresentou cupins de madeira seca, contra $5(41,6 \%)$ sem cupins.

As aberturas externas das edificações são feitas de madeiras maciças e mais resistentes, que apesar de mais expostas a ataques de alados, oferecem maior resistência à agentes biodeterioradores.

Foi constatada a ocorrência de uma única construção que possuía rodapés de madeira e este estava atacado por cupins $(8,3 \%)$. É importante salientar que esta porcentagem refere-se ao número total de amostragem. No caso de considerar-se apenas as edificações com rodapés de madeira, 100\% dos rodapés foram atacados por cupins.

Dos dois imóveis comerciais que tinham forros de madeira, em apenas um foram encontrados cupins de madeira seca $(8,3 \%)$. 
Quanto ao madeiramento dos telhados e dos beiras, das 11 edificações que possuíam essas peças de madeira, nenhuma foi atacada por cupins.

As madeiras utilizadas para a construção dos telhados são duras e resistentes ao ataque de insetos xilófagos, por isso, elas são menos atạcadas por cupins. Além disso, o madeiramento do telhado está protegido pela cobertura e pelo forro dificultado o acesso de cupins a essas peças.

Foi também observado que dentre as edificações 12 edificações comerciais, $6(50,0 \%)$ possuíram alguma peça atacada por cupins.

\subsubsection{Número de focos de cupins nas edificações e tipos de materiais atacados}

Os resultados apresentados a seguir são referentes ao número total de focos de cupins nas edificações.

Pode-se observar que dos 16 focos de cupins, distribuídos has 6 edificações comerciais com ocorrências de cupins, 8 (50,0\%) eram em madeira maciça, $2(12,5 \%)$ ocorreram em chapa dura e $6(37,5 \%)$ eram em sarrafeados.

Foi constatado que a grande diferença entre as edificações comerciais e as edificações residenciais é o tipo de material empregado no seu interior, ou seja, quando em edificações residenciais as divisões são feitas em alvenaria, nos imóveis comerciais as divisórias, que são colocadas após a execução da obra, são freqüentemente feitas de chapa dura de fibra ou de compensado e mais raramente de madeira maciça.

Apesar de não ter sido observado com grande freqüência neste trabalho, Smith \& Zungoli (1995) observaram que infestações por térmitas associadas a 
utilização de chapa dura de fibra não é incomum. Os autores acreditam que os cupins são especialmente atraídos por este material.

A atração dos cupins pela chapa dura de fibra pode ser explicada pela sua constituição, pois, de acordo com Forest Products Laboratory (1999), ela é feita a partir de madeiras pouco resistentes e sem a adição de cola, ou seja, este tipo de chapa é prensado à quente e a cola é a lignina contida na madeira, o que não causa modificações suficientes na madeira que compõe o painel que a torne impalatável ou muito dura para o consumo por cupins

Quanto aos sarrafeados, assim como o que foi citado anteriormente, as chapas de madeiras externas são feitas de madeiras pouco resistentes, assim como os sarrafos internos. Os espaços entre os sarrafos oferecem espaço para o estabelecimento de cupins.

\subsubsection{Presença de cupins e idades das edificações}

As idades das edificações comerciais visitadas, variaram entre 0 e 70 anos, sendo que $25 \%$ das mesmas estavam entre 15 e 30 anos.

Verificou-se (Tabela 5) que em edificações novas, de 0 a 15 anos, apenas $16,6 \%$ apresentaram cupins, contra $25,0 \%$ desta classe nas quais não houve ocorrência de cupins. Na classe de 15 a 30 anos, esta proporção se inverte: $25,0 \%$ delas apresentaram cupins e $16,6 \%$ não apresentaram. 
TABELA 5. Distribuição das freqüências absolutas e relativas das ocorrências de cupins em edificações comerciais agrupadas em classes de idades. A (porcentagem dentro da classe) e B (porcentagem sobre o total de residências amostradas).

\begin{tabular}{cccccc}
\hline \hline $\begin{array}{c}\text { Classes (Idade) } \\
\text { Anos }\end{array}$ & Com Cupins & A & Sem Cupins & A & B \\
\hline 0115 & 2 & 40,0 & 3 & 60,0 & 41,6 \\
$15-130$ & 3 & 60,0 & 2 & 40,0 & 41,6 \\
$30-145$ & 0 & 0 & 1 & 100,0 & 8,4 \\
$45-170$ & 1 & 100,0 & 0 & 0 & 8,4 \\
\hline & 6 & 50,0 & 6 & 50,0 & 100,0 \\
\hline \hline
\end{tabular}

Considerando-se apenas as duas primeiras classes de idades, podería-se dizer que a probabilidade de infestações por cupins tende a aumentar com a idade da edificação, mas esta relação não é clara dado o reduzido número de amostras, principalmente em edificações com mais de 30 anos.

\subsubsection{Relação entre ocorrência de cupins e umidade}

Quando a quantidade de umidade é maior, observou-se um aumento na ocorrência de cupins (de madeira seca), que foi de $16,6 \%$, contra $8,4 \%$ de não ocorrência de cupins (Tabela 6). 
TABELA 6. Freqüências absolutas e relativas de cupins em diferentes condições de umidade em edificações comerciais.

\begin{tabular}{ccccc}
\hline \hline Umidade & Com Cupins & $\%$ & Sem Cupins & $\%$ \\
\hline Nenhuma & 2 & 28,6 & 5 & 71,4 \\
Pouca & 2 & 66,6 & 1 & 33,3 \\
Muita & 1 & 50,0 & 1 & 50,0 \\
\hline & 5 & 41,6 & 7 & 58,4 \\
\hline
\end{tabular}

Apesar disso, devido ao pequeno número de amostras, a relação entre a presença de umidade e ocorrência de cupins de madeira seca não é clara. Possivelmente, esta relação ocorra com resultados semelhantes aos dos imóveis residenciais.

\subsubsection{Móveis}

Dentre as 12 edificações comerciais visitadas, foram encontrados 8 móveis infestados por cupins.

Com relação ao material do qual eram feitos, o material atacado com maior freqüência foi a madeira maciça, em número de $6(75,0 \%)$,e em seguida a chapa dura com 2 móveis atacados $(25,0 \%)$.

Foi verificado que os móveis das edificações comerciais visitadas, pelos próprios fins a que se destinavam (borracharia, loja de autopeças, loja de brocas, serralheiria, etc.), não eram feitos de madeiras mais resistentes ou 
mesmo tratadas. Desta forma, pode-se atribuir a ocorrência de cupins em móveis de madeira maciça à sua baixa resistência.

Quanto à ocorrência de cupins em móveis de chapa dura, pode-se utilizar as mesmas considerações feitas para as peças de chapa dura presentes na edificação.

Devido ao pequeno número de amostras não foi possível estabelecer relação entre ocorrência de cupins e a idade dos móveis.

\subsubsection{Análise conjunta das edificações e móveis}

Considerando-se todas as quadras cujas edificações comerciais foram inspecionadas, pode-se separar as infestações em três grupos: as que apresentaram cupins tanto em peças da construção como em móveis, em número de $5(71,4 \%)$ as que apresentaram cupins apenas em móveis, em número de $1(14,3 \%)$ e as que apresentaram cupins somente na edificação, em número de $1(14,3 \%)$.

Neste caso, pode-se considerar que o fato de se ter alguma peça atacada por cupins nas edificações favorece o alastramento das infestações, no entanto esta afirmação deve ser confirmada a partir de uma maior amostragem.

O menor número de casos de infestações por cupins nas edificações comerciais pode ser explicado pelas constantes desinsetizações. Normalmente as desinsetizações não são específicas para cupins, mas estes podem ser descobertos no momento da inspeção prévia à desinsetização, o que contribui para a prevenção de infestações por térmitas. 


\subsubsection{Arborização}

Foi verificado que as edificações comerciais do Bairro São Dimas, são pouco arborizadas, sendo que em grande parte possui quintal cimentado ou pavimentado com cerâmica. Estes locais são utilizados como estacionamentos para clientes. Desta forma, verificou-se que $75,0 \%$ das edificações comerciais não possuem jardins ou árvores, e dentre os $25,0 \%$ de edificações que possuem um ou outro, não apresentaram cupins.

\subsection{Estrato 3 - Prédios de apartamentos}

\subsubsection{Edificação}

\subsubsection{Número de prédios de apartamentos com cupins e suas partes mais freqüentemente atacadas}

Dentre os prédios de apartamentos, a madeira é utilizada preferencialmente em peças de acabamento, tais como aberturas internas (portas e marcos); balcões da recepção, pisos e rodapés de salões de festas e de jogos, portas externas dos apartamentos e portas dos elevadores. A madeira também é utilizada em quadros de força e entre as juntas de dilatação, bem como em formas para concreto que permaneceram nas construções após seu término.

Verificou-se que dentre os 13 prédios inspecionados em apenas dois ocorreu cupins $(15,4 \%)$. Os cupins estavam presentes nas casas de força dos prédios. Em um dos prédios ocorreu cupins de madeira seca no primeiro. andar e no outro ocorreu cupins subterrâneos no subsolo. 
4.3.1.2. Número de focos de cupins nas edificações e tipos de materiais atacados

Duas edificações apresentaram 3 focos de cupins, sendo que um foco $(33,3)$ estava em madeira maciça, e dois outros, em compensados $(66,6)$. Os cupins que atacaram a madeira maciça eram cupins de madeira seca e os que atacaram os compensados eram cupins subterrâneos.

\subsubsection{Presença de cupins e idade da edificação}

Embora os prédios que apresentaram cupins estejam entre os mais antigos, não é possivel afirmar que haja tendência em aumentar a probabilidade de infestações por cupins com a idade da edificação, visto que o número de amostras é pequeno, não possibilitando que estas relações sejam feitas (Tabela 7 ).

TABELA 7. Distribuição das freqüências absolutas e relativas das ocorrências de cupins em prédios de apartamentos de diferentes idades.

\begin{tabular}{cccccc}
\hline $\begin{array}{c}\text { Classes (Idade) } \\
\text { Anos }\end{array}$ & Com Cupins & $\%$ & Sem Cupins & $\%$ & Total \\
\hline $0+10$ & 0 & 0 & 6 & 100,0 & 6 \\
$10-120$ & 0 & 0 & 5 & 100,0 & 5 \\
$20-130$ & 1 & 100,0 & 0 & 0 & 1 \\
$30-140$ & 1 & 100,0 & 0 & 0 & 1 \\
\hline \hline
\end{tabular}




\subsubsection{Relação entre ocorrência de cupins e presença} de umidade

Dentre os 13 prédios inspecionados, apenas um apresentou umidade em grande quantidade, proveniente do contato direto entre o madeiramento das caixas de força e o solo e nas juntas de dilatação do subsolo. Nesse local foram encontrados focos de infestação por cupins subterrâneos (Figura 11). Sobre esta edificação, que embora tenha sido a única a apresentar cupins subterrâneos, pode-se considerar que a presença de água em abundância facilitou a infestação por esses cupins.

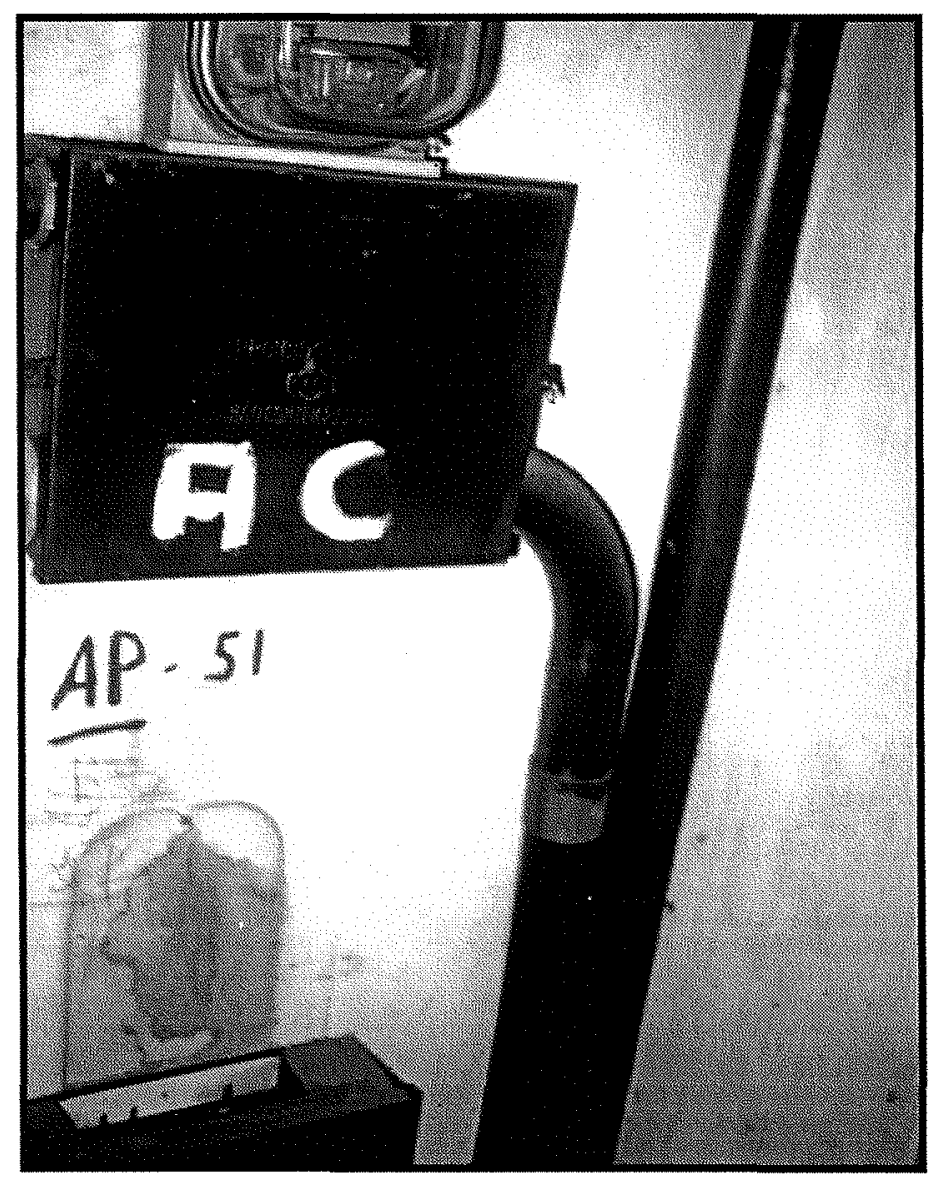

FIGURA 11. Casa de força de um prédio de apartamentos. A mancha na parede é de uma pequena estrutura de ninho de cupins subterrâneos que foi desmanchada pelos funcionários do prédio. 
As condições de umidade apresentadas nesta edificação, são consideradas por Alves \& Berti Filho (1995), Bareia (S.d.), Edwards \& Mill (1986); Fontes (1995a), Lelis (1999), Lepage et al. (1986) e Spear (1970), como extremamente favoráveis à instalação de cupins subterrâneos.

Segundo Potter (1997), muitas infestações termíticas em edificações são decorrentes do contato direto entre a madeira estrutural e o solo. Este contato fornece ao cupim acesso simultâneo ao alimento, umidade, abrigo e acesso direto ao interior da estrutura.

Quanto ao caso de ocorrência de cupins subterrâneos acredita-se que haja uma estrutura de ninho entre a parede de madeira da casa de força e o solo. Embora tenha-se essa suspeita, deve-se considerar que cupins subterrâneos possuem áreas de forrageamento muito extensas e podem estar apenas se alimentando nesta edificação.

Também não se deve excluir a possibilidade da existência de um ninho secundário, pois, segundo Lelis (1999), uma colônia de Coptotermes havilandi pode apresentar mais de uma estrutura de ninho independente, com rainha de substituição ou neotênica e sem contato com o solo.

Quanto ao prédio que teve focos de cupins de madeira seca, estes também estavam na casa de força do prédio. Neste caso, não havia grande quantidade de umidade, visto que esta estava no primeiro andar, sem contato com o solo e bastante arejada. Provavelmente a ocorrência de cupins seja devida a pouca resistência da madeira, da qual era feita a estrutura da casa de força, e também ao fato desta estar mais expostas ao ambiente externo ao prédio. 


\subsubsection{Móveis}

Não foram encontrados cupins em móveis das áreas comuns dos prédios de apartamentos.

Estes resultados podem ser decorrentes do fato de haver baixos indices de ocorrências de cupins em prédios de apartamentos, sendo que a constante manutenção realizada pelos funcionários, não permite a permanência de focos de cupins nessas áreas, pois assim que detectados são rapidamente eliminados.

\subsubsection{Construção e móveis}

Os cupins encontrados neste estrato estavam atacando somente componentes da edificação

\subsubsection{Arborização}

Foi verificado, neste trabalho, que todos os condominios são arborizados e possuem jardins. Dentre eles apenas 1 apresentou cupins em seu jardim $(7,7 \%)$.

Esse resultado pode ser atribuído aos cuidados dispensados a jardinagem dos prédios. Todos os prédios possuem jardineiros que fazem diariamente manutenção das áreas verdes, à exceção do único prédio que apresentou cupins próximo a uma árvore.

\subsection{Espécies de cupins encontradas}

O Bairro São Dimas não apresentou grande diversidade de espécies de cupins. 
Nas edificações residenciais e em seus móveis houve focos apenas de cupins de madeira seca, Cryptotermes brevis (Figura 12).

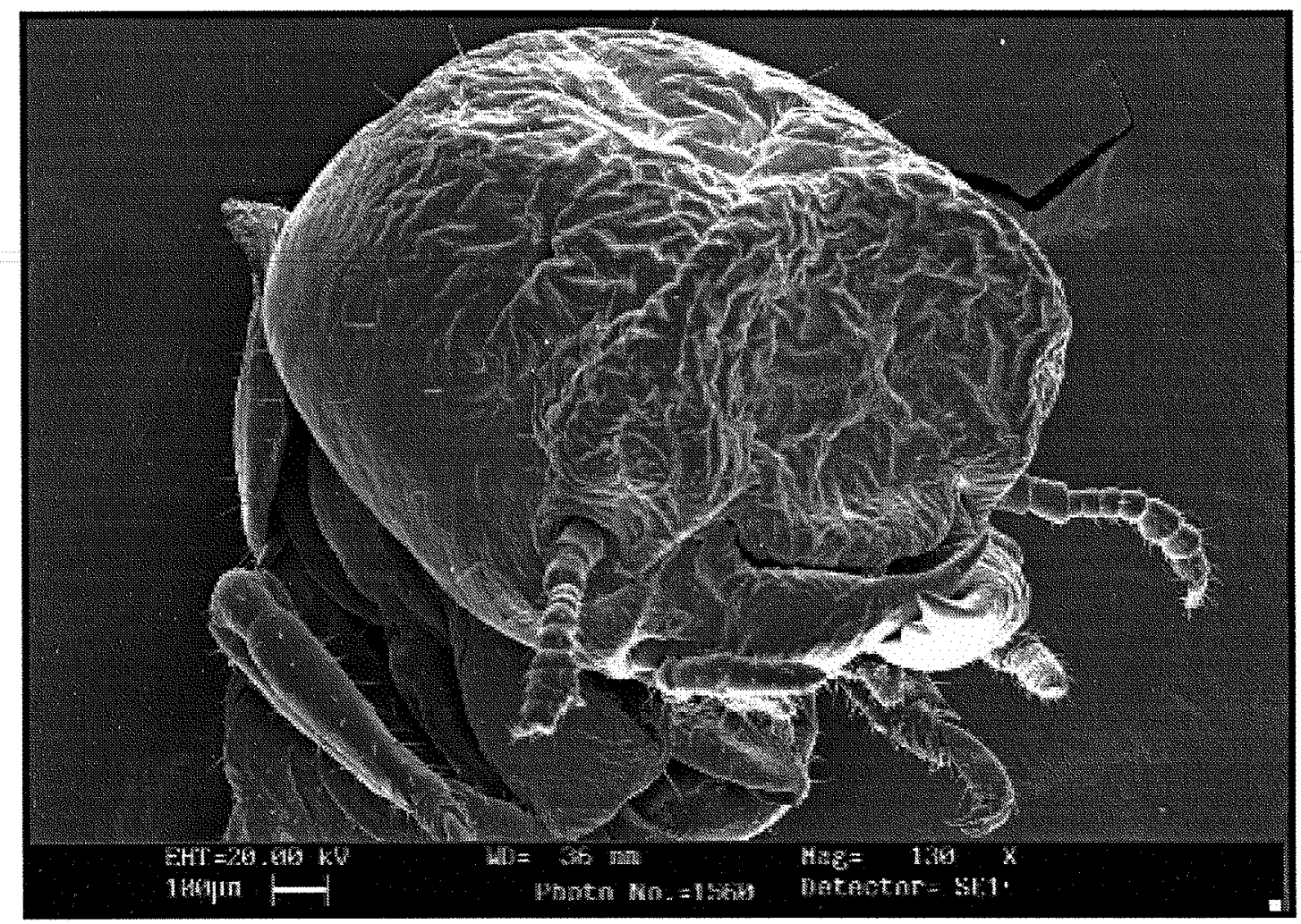

FIGURA 12. Foto de microscópio eletrônico de varredura de soldado de Cryptotermes brevis. As rugosidades na cabeça são características próprias da espécie.

Os cupins encontrados nas edificações comerciais e em seus móveis foram somente os de madeira seca, Cryptotermes brevis.

Em prédios de apartamentos ocorreram cupins, apenas na edificação, sendo que estavam presentes a espécie de cupim de madeira seca Cryptotermes brevis e a espécie de cupim subterrâneo Coptotermes havilandi (Figura 13). 


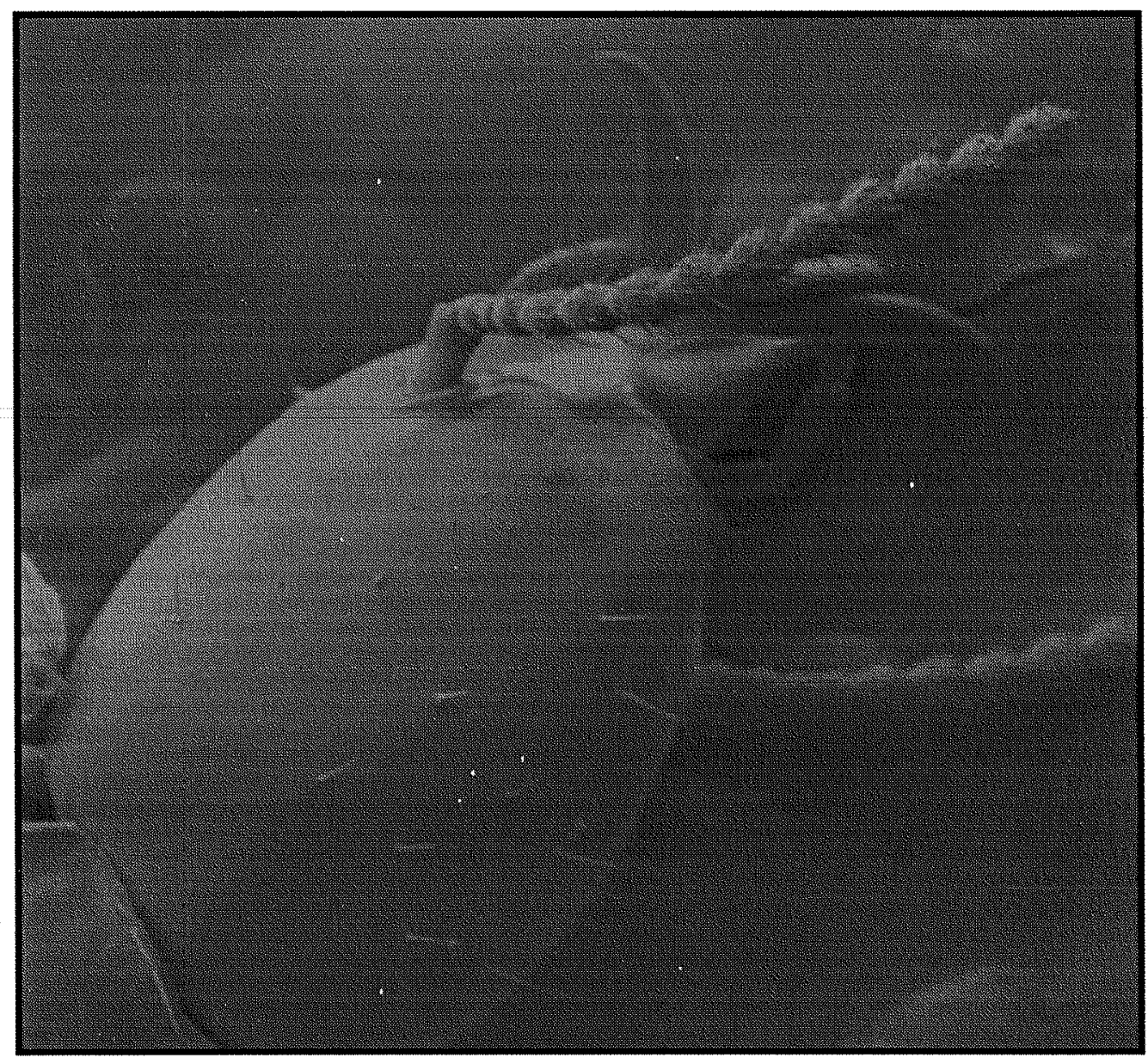

FIGURA 13. Foto de microscópio eletrônico de varredura de um soldado de Coptotermes havilandi (aumento de 50x).

É importante ressaltar que foram coletados espécimens de cupins de madeira seca Cryptotermes brevis em 7 edificações. A coleta de cupins nem sempre foi possível devido a necessidade de destruir-se as peças onde estavam as colônias. Nos demais imóveis foram coletados apenas os resíduos fecais dos cupins que estavam infestando as peças (Figura 14). A partir da análise destes residuos constatou-se que todos eram de cupins de madeira seca e pode-se, então, considerar que eles pertençam a espécie Cryptotermes brevis, pois todos os espécimens identificados no bairro eram desta espécie. 


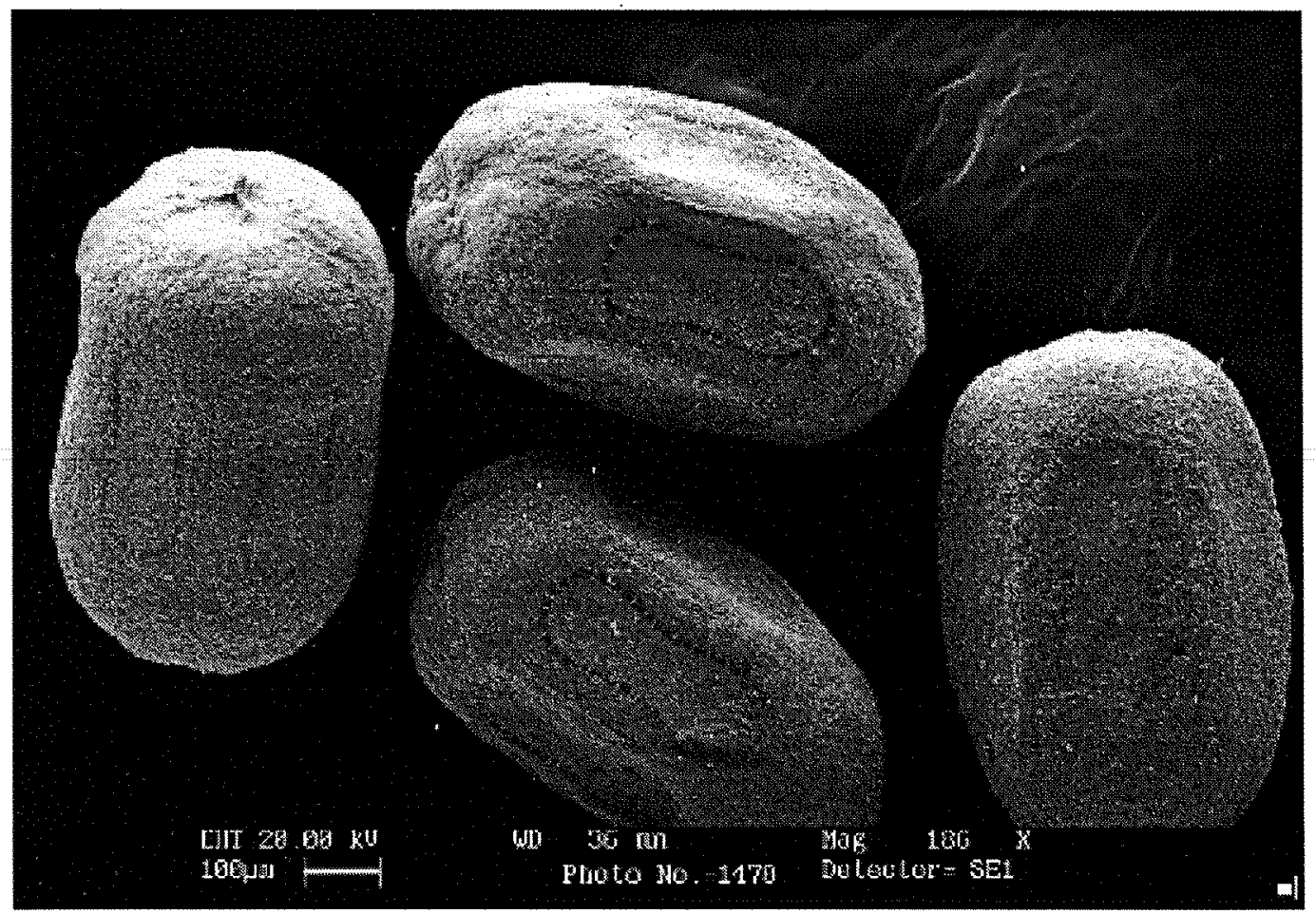

FIGURA 14. Foto em microscópio eletrônico de varredura de resíduos fecais de cupins de madeira seca.

\subsubsection{Cupins de madeira seca}

No bairro estudado, observou-se que houve maior freqüência de cupins de madeira seca (Cryptotermes brevis Walker).

Esta ocorrência exclusiva de cupins de madeira seca em imóveis residenciais e comerciais, pode ser influenciada pela falta de condições favoráveis à instalação de cupins subterrâneos devido a pequena quantidade de umidade e pelas próprias características da região que apresenta longos períodos de seca, ou mesmo do bairro, que possui poucas áreas sombreadas e úmidas pelo reduzido número de árvores. Estas condições são considẹradas 
por Hagsma \& Rust (1995), Hedges (1998), Howard et al. (1982) e Rudolph et al. (1990) como limitantes para a sobrevivência de cupins subterrâneos.

As condições de temperatura e umidade da região, não influem, no entanto, no estabelecimento de cupins de madeira seca, que sobrevivem longos períodos com pouca umidade e com temperaturas elevadas. Estas colocações são concordantes com o que foi constatado por Edwards \& Mill (1986); Waller \& La Fage (1986) e Rudolph et al., (1990), sobre baixo requerimento de umidade e grande tolerância às condições secas, por periodos prolongados, apresentados pelos cupins pertencentes a este grupo.

A grande resistência de Cryptotermes brevis é reforçada por Becker (1978), que relatou sua sobrevivência e desenvolvimento em condições de temperatura, umidade e nutrição extremamente desfavoráveis, em Berlim na Alemanha.

A ampla distribuição de cupins de madeira seca no bairro São Dimas era um resultado esperado, frente à sua distribuição nas maiores regiões zoogeográficas do mundo. Esses são cupins considerados cosmopolitas e ocorrem com grande freqüência no ambiente doméstico (Bacchus, $1987^{2}$, citado por Bandeira et al., 1998).

O bairro São Dimas apresentou distribuição uniforme de cupins de madeira seca. Tal condição pode determinar a situação de infestação do bairro

${ }^{2}$ BACCHUS, S. A taxonomic and biometric study of the genus Cryptotermes (Isoptera, Kalotermitidae). Tropical Pest Bulletin, n.7, p.1-91, 1987. 
por esses cupins, que podem se alastrar para outros bairros se não forem tomadas medidas que impeçam esta dispersão.

É importante salientar que, apesar dos cupins de madeira seca serem menos vorazes do que os cupins subterrâneos, podem causar danos expressivos às construções ao longo do tempo. No Brasil, os gêneros mais encontrados de cupins de madeira seca são Cryptotermes e Eucryptotermes (LELIS, 1976).

\subsubsection{Cupins subterrâneos}

Foi encontrado apenas um caso de cupim subterrâneo no bairro São Dimas em Piracicaba, identificado como Coptotermes havilandi (Holmgren).

$\mathrm{Na}$ Cidade de São Paulo, essa espécie de cupim está bastante disseminada e causa prejuizos consideráveis (Lelis, 1994). No entanto, podese considerar que o Bairro São Dimas não apresenta uma infestação por cupins subterrâneos, mas é importante levar-se em conta que esta espécie se dispersa rapidamente e pode vir a causar prejuízos futuramente.

O fato de não terem sido encontrados mais casos de cupins subterrâneos pode ser atribuído ao tipo de clima da região de Piracicaba e pela baixa precipitação pluviométrica, apenas 1.070,6mm (CIAGRI, 1999). Desta forma, não são fornecidas as condições, principalmente de umidade, para a manutenção das colônias de cupins pertencentes a esse grupo, visto que segundo Robinson (1996), diferenças regionais de temperatura e umidade podem influenciar na distribuição de térmitas.

Apesar do clima de Piracicaba ser desfavorável a esse cupim subterrâneo, é importante que se tomem medidas preventivas contra seu ataque, pois os ambientes urbanos, através das atividades do homem, 
disponibilizam outras fontes de água para os cupins subterrâneos, o que pode eliminar os efeitos da precipitação, possibilitando assim o estabelecimento de colônias. Além disso, a região sudeste do Brasil é citada por Fontes (1995c), como uma das mais assoladas por ataques da espécie oriental Coptotermes havilandi.

No bairro estudado ainda há muito espaço livre e as edificações não são muito próximas umas das outras como em grandes cidades. Segundo Lelis (1999), o aglomero das edificações favorece as infestações por cupins subterrâneos, pois estes passariam com maior facilidade de um prédio para outro.

\subsubsection{Cupins na arborização urbana}

O cupim encontrado nas raizes de uma árvores de edificação residencial, pertence à espécie Embiratermes sp. (Termitídae: Nasutitermitidae), sendo que não foram vistos sinais de ataques desse cupim em construções próximas.

Próximo a uma árvore de um prédio de apartamentos foi encontrado um ninho de Nasutitermes sp. (Termitídae: Nasutitermitidae) (Figura 15). 


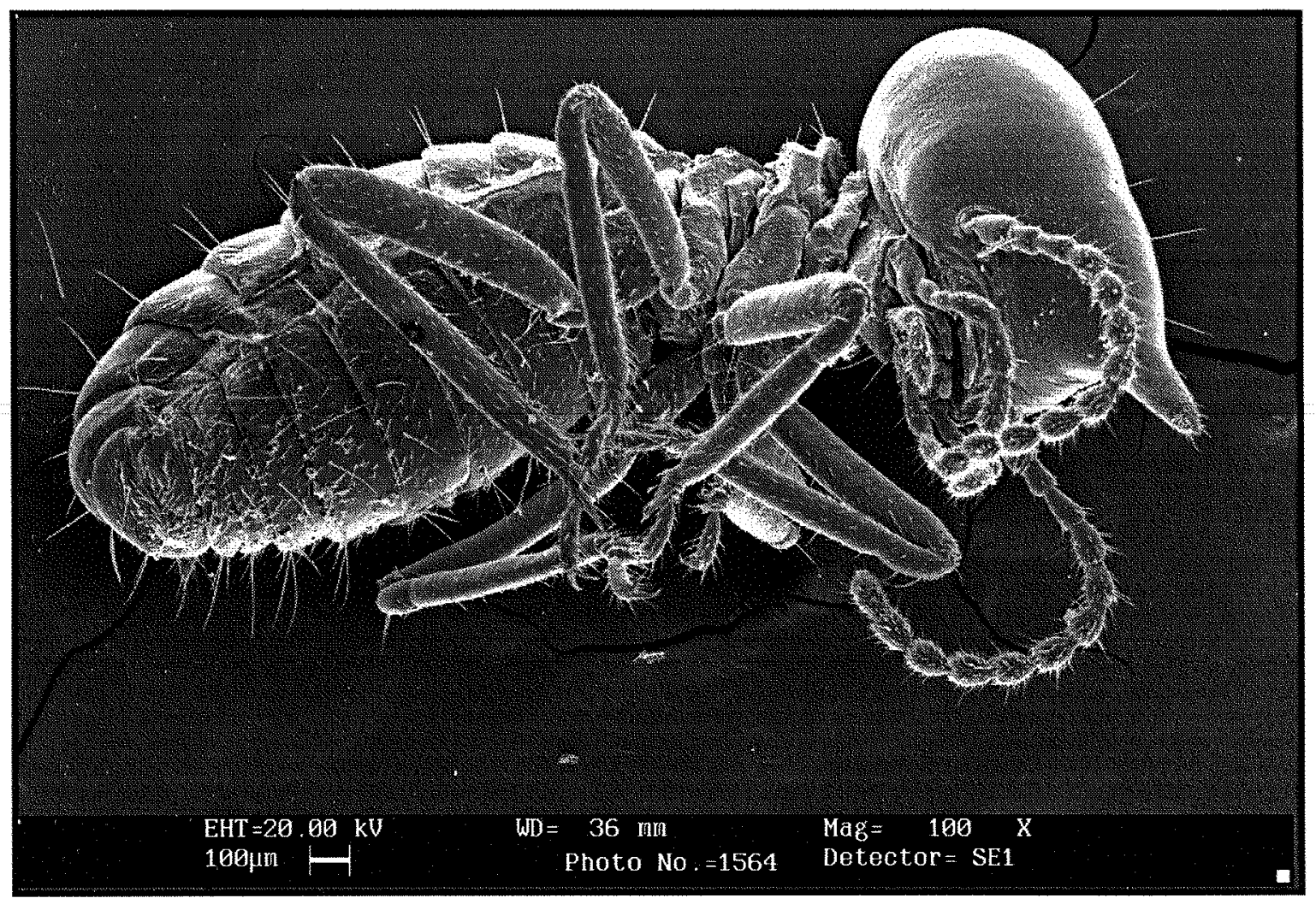

FIGURA 15. Foto em microscópio eletrônico de varredura de soldado Nasutitermes sp.

Os cupins encontrados nas árvores não foram observados infestando edificações. É importante considerar que o fato de haver cupins em árvores próximas a uma edificação não significa necessariamente que há um caso de infestação por esses cupins pois, segundo Milano (1998), existem cupins que embora infestem árvores ou invadam as residências não causam qualquer dano as mesmas. O autor chama a atenção para a importância da identificação da espécie invasora para se evitarem tratamentos químicos desnecessários e possiveis contaminações ambientais decorrentes de tratamentos mal dimensionados.

Apesar disso, é aconselhável o monitoramento desses cupins para garantir que não haja qualquer tipo de dano às edificações próximas pois, de 
acordo com Bandeira et al. (1998), espécies de Nasutitermes são pouco exigentes quanto a escolha do alimento e atacam tanto madeiras úmidas quanto secas, duras ou moles e trabalhadas ou não. Portanto, o fato de haver colônias de Nasutitermes próximas podem levar a infestações nas edificações.

\subsection{Espécies de madeiras atacadas nas edificações}

A madeira de Araucaria angustifolia, de acordo com Forest Products Laboratory (1999), não possui resistência natural à biodeterioração. Essa madeira é muito utilizada principalmente em peças de acabamento por ter textura uniforme, estar disponível em tábuas de grandes dimensões e sem bolsas de resina, ter facilidade de ser pregada e colada e de aceitar bem 0 acabamento. Foi observado, neste trabalho, que a madeira de pinho do Paraná foi amplamente utilizada em peças de acabamento das edificações residenciais e comerciais visitadas, sendo que não receberam nenhum tratamento preservativo contra 0 ataque de cupins.

No caso do ataque de cupins de madeira seca, observado num parapeito de janela de peroba (Figura 16), verificou-se que apenas o alburno foi atacado, embora de acordo com Forest Products Laboratory (1999), o cerne da peroba rosa seja resistente ao ataque de fungos, mas susceptivel ao ataque de cupins de madeira seca. A madeira de peroba é bastante utilizada em funçōes estruturais, e tão resistente quanto a madeira de carvalho, é moderadamente pesada e aceita satisfatoriamente a colagem e os acabamentos. 


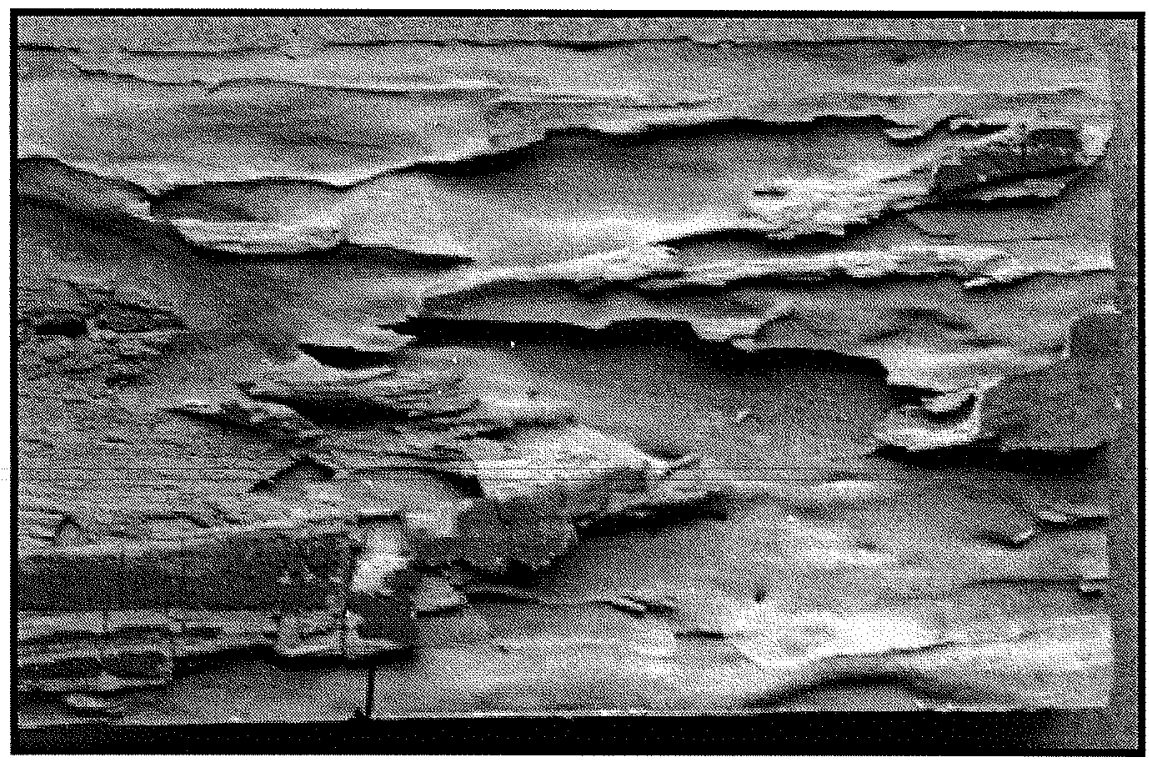

FIGURA 16. Parapeito de peroba de imóvel residencial atacado por cupins de madeira seca.

\subsection{Distribuição dos diferentes grupos de cupins no bairro São Dimas}

Os cupins de madeira seca estão amplamente distribuídos no bairro, sendo que nas quadras próximas do rio Piracicaba, há maior número de focos por quadra. O número de focos tende a diminuir nas quadras conforme se afastam do rio (Figura 17).

Os cupins subterrâneos ocorreram apenas na parte sul do bairro. Isto sugere que pode haver mais casos de infestação, por esse tipo de cupim, em áreas próximas. 


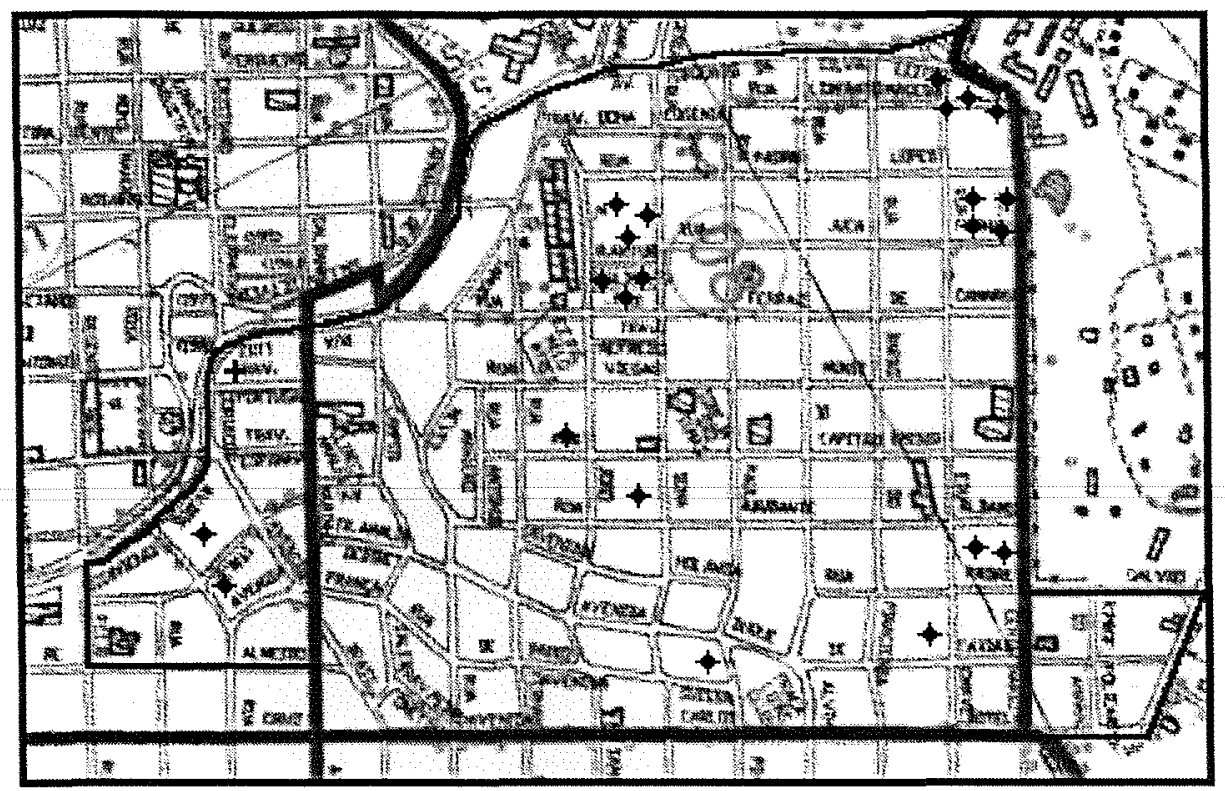

FIGURA 17. Distribuição dos diferentes grupos de cupins que ocorrem em edificações do Bairro São Dimas, onde $\uparrow$ representa os cupins de madeira seca e + representa os cupins subterrâneos).

\subsection{Outras considerações}

Não foram observados, neste trabalho, ataques de cupins de madeira úmida (Termopsidae). Segundo Su \& Scheffrahn (1990), esses cupins atacam madeiras úmidas e já degradadas por fungos em construções de várias partes do mundo. No Brasil, Lelis (1976) relata que espécies de cupins de madeira úmida apenas foram registrados em árvores vivas, mas nunca atacando edificações.

É importante salientar a falta de conhecimento das pessoas sobre os cupins e sobre as madeiras utilizadas nas construções de seus imóveis.

Considerando-se os proprietários ou locatários dos 52 imóveis, residenciais e comerciais, somente três pessoas $(5,8 \%)$ sabiam que as aleluias 
ou siriris são cupins em revoada com fins reprodutivos e que infestam as peças de madeira e os móveis nos seus prédios.

Também são confundidos os sintomas do ataque de cupins de madeira seca com os danos causados por outros organismos biodeterioradores, tais como fungos (Figura 18), formigas (Figura 19) e brocas (Figura 20). Estas amostras foram feitas de peças fornecidas pelos moradores como sendo atacadas por cupins de madeira seca.

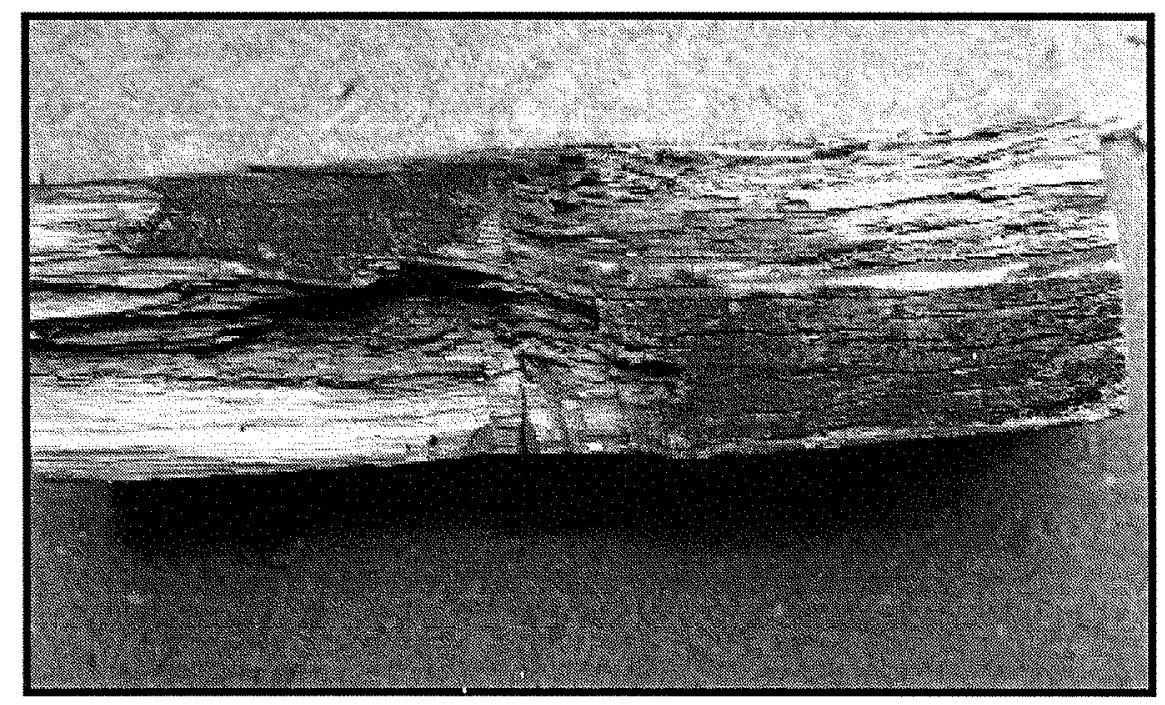

FIGURA 18. Madeira atacada por fungos. 


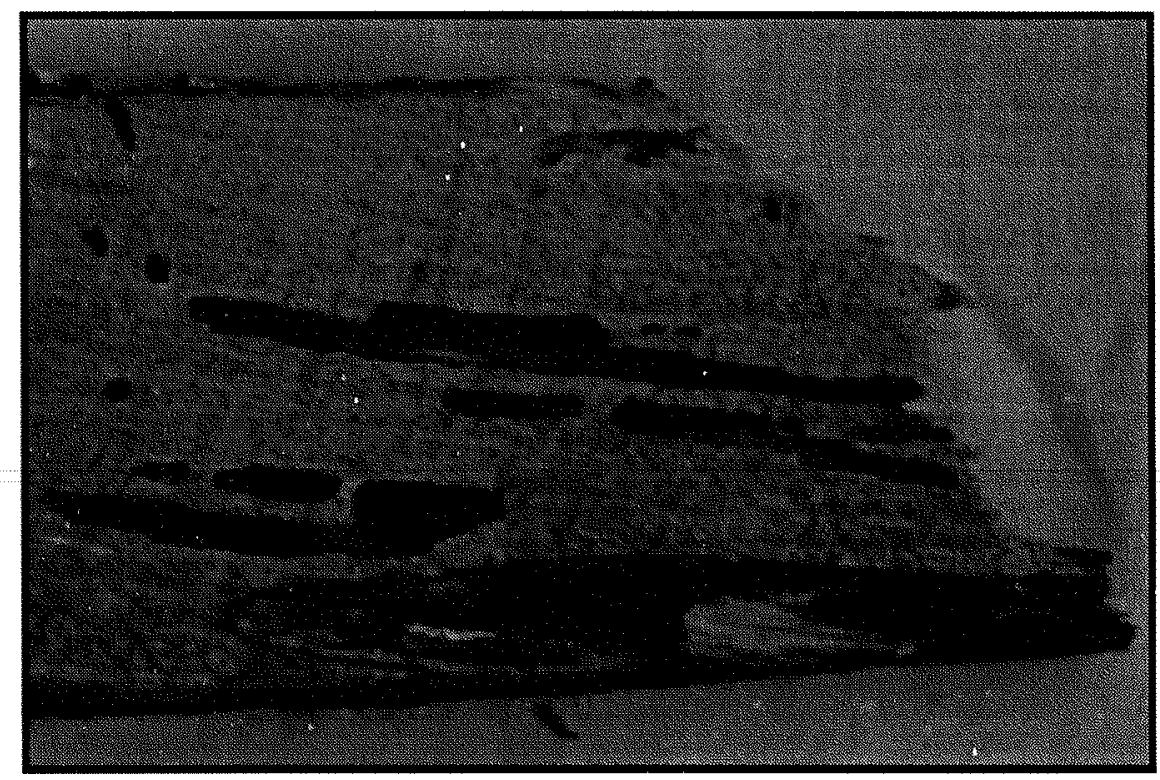

FIGURA 19. Peça de madeira atacada por formigas carpinteiras.

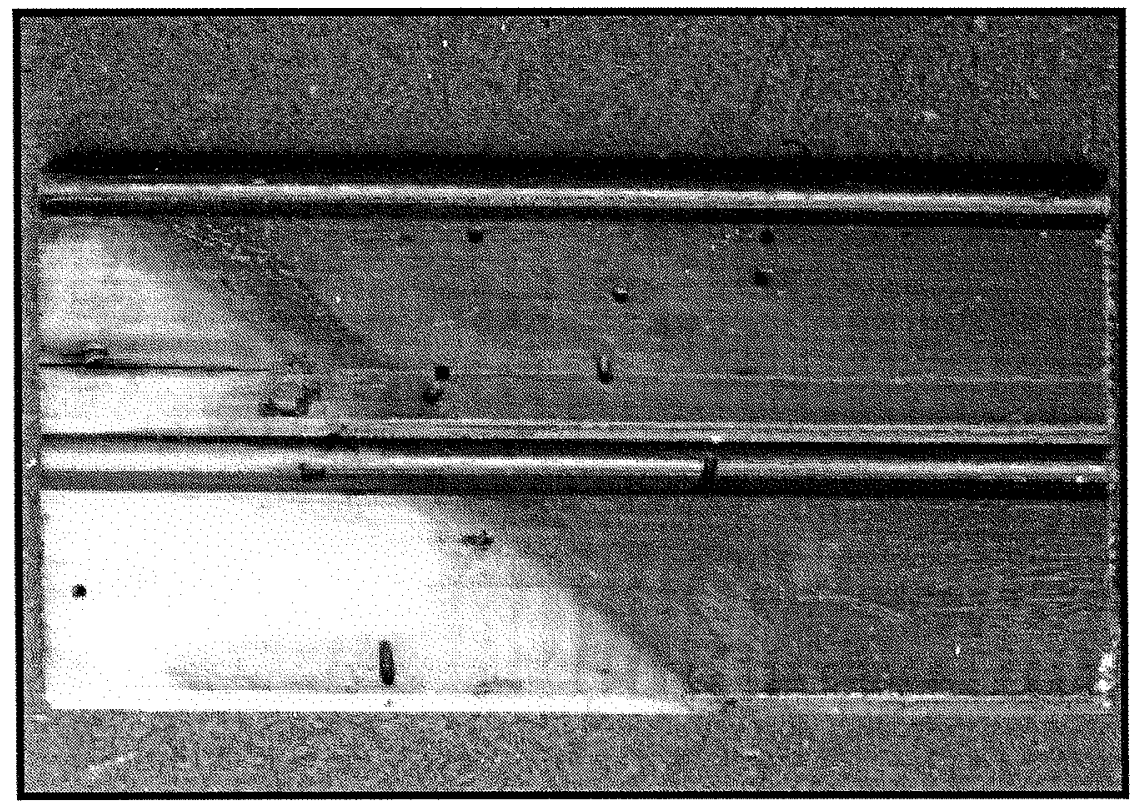

FIGURA 20. Peça de madeira atacada por brocas. 
Sobre os sintomas de ataques de cupins subterrâneos, a maior parte da população desconhece, porém 4 zeladores de prédios de apartamentos tinham conhecimento sobre esses cupins através de treinamentos profissionais.

Quanto às madeiras suscetíveis aos ataques de cupins, as de pinho do Paraná são reconhecidamente pouco resistentes ao ataque por fungos (podridão), processo de biodeterioração mais conhecido pela população. No entanto, quando se fala em peroba, todos os proprietários dos imóveis cujos madeiramentos dos telhados são desta madeira, garantem que ela é praticamente indestrutível.

A ampliação deste estudo para outros bairros da cidade de Piracicaba seria interessante, pois proporcionaria maiores conhecimentos sobre a dispersão das espécies de cupins e os fatores que a influenciam. 


\section{CONCLUSÕES}

-Em edificações residenciais a ocorrência de cupins tende a aumentar com a umidade da madeira. Nas edificações comerciais e nos prédios de apartamentos esta relação não é clara;

-O risco de infestações por cupins tende a aumentar com a idade das edificações;

- O número de focos de cupins nas edificações residenciais tende a aumentar com a idade da construção. Em edificações comerciais e prédios de apartamentos esta relação não é clara;

- A presença de cupins na edificação não implica, necessariamente, na sua presença nos móveis e vice-versa;

- Madeiras maciças pouco resistentes e sem tratamento são mais atacadas por cupins, em relação aos painéis à base de madeira;

- Não há relação entre ocorrência de cupins em árvores e as infestações das edificações no bairro São Dimas em Piracicaba;

-Há pouco conhecimento, por parte da população, sobre a problemática dos cupins em edificações e há confusão entre os sintomas do ataque de cupins e de outros organismos biodeterioradores;

- Não foram tomadas medidas preventivas contra cupins quando da execução das obras. 


\section{REFERÊNCIAS BIBLIOGRÁFICAS}

ABER, A; FONTES, L. R. Reticulitermes lucifugus (Isoptera: Rhinotermitidae) a pest of wooden structures, is introduced into the South American Continent. Sociobiology, v 21, n.3, p.335-339, 1993.

ALVES, S. B. \& BERTI FILHO, E. Controle dos cupins nas construções urbanas e rurais. Piracicaba: ESALQ/CENA, 1995. (Boletim técnico n.4 da Universidade de São Paulo, Campus "Luiz de Queiroz).

ANTONELLI, A.; WHITWORTH, T.; THOMASSON, G. A. key to identification of pacific northwest wood-destroying pests based on wood damage. Waschington State University. 1996. 6p. www. cooptext.cahe.wsu.edu/infopub/eb1814.

ARAUJO, R. L. Catálogo dos Isoptera do novo mundo. Rio de Janeiro: Academia Brasileira de Ciências, 1977. 92p.

ARAUJO, R.L. Térmitas prejudiciais às madeiras. In: MARICONI, F. A .M.; ZAMITH, A. P. L.; ARAÚJO, R.L; OLIVEIRA, F. A. M.; PINCHIN, R. (Eds.).Inseticidas e seu emprego no combate às pragas. São Paulo: Nobel, 1980. p.100-123.

ARAUJO, R.L. Termites of the neotropical region. In: KRISHNA, K. \& WEESNER, M. (Ed.). Biology of termites. New York: Academic Press, 1970. v.2, cap.12, p.527-576. 
BANDEIRA, A. G.; MIRANDA, C. S.; VASCONCELLOS, A. Danos causados por cupins em João Pessoa, Paraíba - Brasil. In.: FONTES, L. R. \& BERTI FILHO, E. (Eds.). Cupins: O desafio do conhecimento. Piracicaba: FEALQ, 1998.p. 75-85.

BANDEIRA, A. G. Danos causados por cupins na Amazônia Brasileira. In: FONTES, L. R. \& BERTI FILHO, E. (Eds.). Cupins: O desafio do conhecimento. Piracicaba: FEALQ, 1998.p. 87-98.

BAREIA, E. Madeira: caracteristicas, deterioração, tratamento. Ministério da Cultura/ Secretaria do Patrimônio Histórico e Artístico Nacional/ Fundação Nacional Pró-Memória, s.d.

BEAL, R.H. Preventing termite attack by adding inceticide to particleboard, hardboard, and plywood adhesive. Forest Products Journal, v.29, n.12, p.29-34, 1979.

BECKER, G. On termites in Central and South America. Revista Floresta, v.9, n.2, p.71-75, 1978.

BONTURI, D. A. O cupim nas instalações elétricas. In.: FONTES, L. R. \& BERTI FILHO, E. (Eds.). Cupins: O desafio do conhecimento. Piracicaba: FEALQ, 1998.p. 99-108.

BROOKS, F. W. Progress towards european standards in in - wood preservatives. In.: THOMPSON, R. The chemistry of wood preservation. Cambridge: Royal Society of Chemistry, 1991. 323p.

CIAGRI - Centro de Informática do Campus Luiz de Queiroz, 1999. Aspectos físicos da Cidade de Piracicaba, SP. http:/lwww. ciagri.usp.br/piracica/aspfis-p.htm (Out. 1999)

COSTA, P. M. Breve história da evolução dos mercados de carbono. Silvicultura, ano XIX, n.75, p.24-33, 1998.

DIMRI, M.P.; SHUKLA, K.S.; MISHRA, S.C. \& SANJAY-KUMAR. Effect of glue line treatment on the termite resistance of plywood. Journal of the Timber 
Development Association of India, v.41, n.4, p.22-28, 1995. / Rèsumo em CAB Abstracts on CD-ROM /

EDWARDS, R. \& MILL, A. E. Termites in buildings: Their biology and control. Felcourt: Rentokil Ltda, 1986. 231p.

FONTES, L. R. Acréscimos e correções ao catalogo dos Isopteras do novo mundo. Revista Brasileira de Entomologia, v.17, n.2, p.137-145, 1983.

FONTES, L. R. Considerações sobre a complexidade da interação entre o cupim subterrâneo, Coptotermes havilandi, e a arborização no ambiente urbano. In.: FONTES, L. R. \& BERTI FILHO, E. (Eds.). Cupins: O desafio do conhecimento. Piracicaba: FEALQ, 1998.p. 109-124.

FONTES, L. R. Cupins em áreas urbanas. In: BERTI FILHO, E. \& FONTES, L. R. (Eds.). Alguns Aspectos Atuais da Biologia e Controle de Cupins. Piracicaba: FEALQ, 1995a. p.57-76.

FONTES, L. R. Sistemática geral de cupins. In: BERTI FILHO, E. \& FONTES,

L. R. (Eds.). Alguns Aspectos Atuais da Biologia e Controle de Cupins. Piracicaba: FEALQ, 1995b. p.11-18.

FONTES, L. R. Termites (Isoptera) que causam infestación en Brasil. In: BERTI FILHO, E. \& FONTES, L. R. (Eds.). Alguns Aspectos Atuais da Biologia e Controle de Cupins. Piracicaba: FEALQ, 1995c. p.163-164.

FOREST PRODUCTS LABORATORY. Wood Handbook- wood as an engineering material. Madison, WI: Department of Agriculture, Forest Service, Forest Products Laboratory, 1999. 463p.

FORTI, L. C. \& ANDRADE, M. L. de. Populações de cupins. In: BERTI FILHO, E. \& FONTES, L. R. (Eds.). Alguns Aspectos Atuais da Biologia e Controle de Cupins. Piracicaba: FEALQ, 1995. P.29-52.

FOWLER, H. G. \& FORTI, L. C. Status and prospects of termite problems and control in Brazil. Sociobiology, v.17, n.1, p.45-56, 1990. 
GOLD, R. E.; HOWELL, H. N.; PAWSON, B. M., WRIGTH, M. S.; LUTZ, J. C. Persistence and bioavailability of termiticides to subterranean termites (Isoptera: Rhinotermitidae) from five soil types and locations in Texas. Sociobiology, n.28, p.337-363, 1996.

GRASSÉ, P-P. Termitologia. Paris: Masson, 1982. v. 1.676p.

GRASSÉ, P.P. Termitologia. Paris: Masson, 1984. v. 2 ..

GRASSÉ, P-P. Traité de zoologie: anatomie, systématique, biologie. Paris:

Masson et cie., 1949. Tome IX, 1117p.

HAAGSMA, K. A. \& RUST, M. K. Colony size estimates, foraging trends, and physiological characteristics of the western subterranean termite (Isoptera: Rhinotermitidae). Entomological Society of America, v.24, n.6, p.15201528, Dec. 1995.

HEDGES, S. Add-on for termite control. Pest Control Technology, p.30-35 Feb, 1998.

HARRIS, W. V. Termites: their recognition and control. England: Longman Group Ltda., 2 ed., 1971. 186p.

HICKIN, N. E. Termites: a world problem. London: Rentokil, 1971. 232p.

HOWARD, R. W.; JONES, S. C.; MAULDIN, J. K. \& BEAL, R. H. Abundance, distribution and colony size estimates for Reticulitermes spp. (Isoptera: Rhinotermitidae) in southern Mississippi. Environmental Entomology, v.11, n.6, p.1920-1293, Dec. 1982.

IMAMURA, Y.; NISHIMOTO, K. \& MOTOKI, H. Termite resistance of flakeboards bonded with isocyanate resin. Mokuzai gakkaishi - Journal of Japan Wood Research Society, v.32, n.10, p.842-845, 1986. / Resumo em CAB Abstracts on CD-ROM /

$\mathrm{KOCH}, \mathrm{P}$. Wood versus nonwood materials in U.S. residential construction: some energy - related global implications. Forest Products Journal, v.42, n.5, p.31-42, May. 1992. 
KOEHLER, P. G. Drywood and other non-subterranean termites. University of Florida. Gainesville. 1996. 4p. http://hammock.ifas.ufl.edu

KOEHLER, P. G.; SU, N. Y.; SCHEFFRANH, R. H. The formosan subterranean termite. University of Florida. Gainesville. 1990. 4p. http://hammock. ifas.ufl.edu

KRISHNA, K. Taxonomy, phylogeny, and distribuion of termites. In: KRISHNA, K. \& WEESNER, M. (Ed.). Biology of termites. New York: Academic Press, 1970. v.2, cap.3, p.127-152.

LAERA, L. H. N. Cupins na arborização urbana no Município do Rio de Janeiro, Brasil. In.: FONTES, L. R. \& BERTI FILHO, E. (Eds.). Cupins: O desafio do conhecimento. Piracicaba: FEALQ, 1998.p. 125-132.

LEE, K. E. \& WOOD, T. G. Termite and soils. London: Academic Press, 1971. 251p.

LELIS, A. T. Cupins urbanos: biologia e controle. In: BERTI FILHO, E. \& FONTES, L. R. (Eds.). Alguns Aspectos Atuais da Biologia e Controle de Cupins. Piracicaba: FEALQ, 1995. p.77-80.

LELIS, A. T. Cupins: prevenção e erradicação. Preservação de Madeiras, v.6-7, n.1, p.51-58, 1976.

LELIS, A. T. Imaginal and neotenic queens of Coptotermes havilandi (Isoptera, Rhinotermitidae) from São Paulo, Brazil: The implication of supplemental reproductives in termite control. Resumo no XIII International Congress of IUSSI. Adelaide, Australia. 1999.

LELIS, A. T. Termite problem in São Paulo City - Brazil. Resumo no XII International Congress of IUSSI. Paris, França. 1994.

LEPAGE, E.S.; GERALDO, F. C.; ZANOTTO, P. A. \& MILANO, S. Métodos de tratamento. In: LEPAGE, E. S. (Coord.). Manual de preservação de madeiras. São Paulo: IPT, 1986. v.II, p.343-419. 
LIN-RIZhao.; FENG, Y. B. \& HUANG, X. S. Ecogeography of Isoptera in Guangxi region, China. Zoological Research, v.17, n.1, p.33-39, 1996. I Resumo em CAB Abstracts on CD-ROM /

MARER, P. Residential Industrial Pestcontrol. Oakland: University California Agriculture and Natural Resourses. Publication 3334, 1991. http://www.ipm.ucdavis.edu/PMG/PESTNOTES

MARICONI, F. A. M.; ZAMITH, A. P.; ARAUJO, R. L.; OLIVEIRA FILHO, A, M.;

PINCHIN, R. Inseticidas e seu emprego no combate às pragas. v.3. São Paulo: Nobel, 1980. 246p.

MILANO, S. Diagnóstico e controle de cupins em área urbana. In.: FONTES, L.

R. \& BERTI FILHO, E. (Eds.). Cupins: O desafio do conhecimento. Piracicaba: FEALQ, 1998.p. 45-74.

MULLER, C.; FREITAG, S.; SCHOLTZ, C. H. \& VAN JAARSVELD, A. S.

Termite (Isoptera) distributions, endemism, species richness and priority conservation areas: consequences for land-use planning in South Africa. African Entomology, v.5, n.2, p.261-271, 1997.

MYLES, T. G. Termite prevention. University of Toronto http://www.utoronto.ca/forest/termite/tips (Oct, 1999).

NOIROT, C. H. The nests of termites. In: KRISHNA, K. \& WEESNER, M. (Ed.). Biology of termites. New York: Academic Press, 1970. v.2, cap.3, p.73125.

NUTTING, W. L. Flight and colony foundation. In: KRISHNA, K. \& WEESNER, M. (Ed.). Biology of termites. New York: Academic Press, 1970. v.2, cap.8, p.233-382.

OLIVEIRA, A. M. F.; LELIS, A. T. de; LEPAGE, E. S.; CARBALLERA LOPEZ, G. A.; SAMPAIO OlIVEIRA, L. C. de; CAÑEDO, M. D. \& MILANO, S. Agentes destruidores da madeira. In: LEPAGE, E. S. (Coord.). Manual de preservação de madeiras. São Paulo: IPT, 1986. v.I, p.99-278. 
POTTER, M. Protecting your home against termites. University of Kentuky College of Agriculture. 1997. http://www.uky:edu/Agriculture/Entomology REINHARD, J.; HERTEL, H.; KAIB, M. Systematic search for food in the subterranean termite Reticulitermes santonensis De Feytard (Isoptera, Rhinotermitidae). Insectes Sociaux. n.4, p.147-158, 1997.

ROBINSON, W. H. Urban entomology: Insect and mite pests in the human environment. 1 ed. London: Chapman \& Hall, 1996.

RUDOLPH, D; GLOCKE, B. \& RATHENOW, S. On the role of different humidity parameters for the survival, distribution and ecology of various termite species. Sociobiology, v.17, n.1, p.129-140, 1990.

SANTINI, E. J. Biodeterioração e preservação da madeira. Santa Maria: CEPEF/FATEC, 1988. 125P.

SCHEFFRAHN, R. H.; SU, N-Y. West Indian powderpost drywood termite Cryptotermes brevis (Walker) (Insecta: Isoptera: Kalotermitidae). http://www.ifas.ufl.edu/ insect/ur...es/west_indian_drywood_termite . (Oct, 1999)

SHUKLA, K.S. \& JOSHI, H.C. Studies on the preservation of playwood: glue line treatmente with the indian. Academy of Wood Science, v.23, n.2, p.15-23, 1992. / Resumo em CAB Abstracts on CD-ROM /

SMITH, B. C. \& ZUNGOLI, P. A. Rigid board insulation in South Carolina: its impact on damage, inspection and control of termites (Isoptera: Rhinotermitidae). Florida Entomologist, v.78. n.3, p.507-515, Sep. 1995. SPEAR, P.J. Principles of termite control. In: KRISHNA, K. \& WEESNER, M. (Ed.). Biology of termites. New York: Academic Press, 1970. v.2, cap.13, p.577-604.

STEWARD, R. C. Microclimate and colony foundation by imago and neotenic reprodutives of dry-wood termite species (Cryptotermes sp.) (Isoptera: Kalotermitidae. Sociobiology, v.7, n.3, p.311-331, 1983. 
STEWARD, R.C. Comparison of the behavioural and physiological responses to humidity of five species of drywood termites, Cryptotermes species. Physiologicas Entomology, v.7, n.1, p.71-82, 1982. / Resumo em CAB Abstracts on CD-ROM /

SU, N-Y.; SCHEFFRAHN, R. H. Economicaly important termites in the United States an their control. Sociobiology, v.17, n.1, p.77-94, 1990.

SU, N-Y; SCHEFFRAHN, R. H. Foraging population and territory of the Formosan subterranean termite (Isoptera: Rhinotermitidae) in a urban environment. Sociobiology, v.14, n.2, p.353-359, 1988.

VAN DEN MEIRACKER, K. G. Pest identification: drywood termites. Pest Control, p.80-82, Feb. 1998.

WALLER, D. A. \& LA FAGE, J. P. Nutritional ecology of termites. In: SLANSKY JR., F. \& RODRIGUEZ, J. C. Nutritional ecology of insects, mites, spiders and related invertebrates. New York: Wiley-Interscience Publication, 1986. Cap.16, p.487-532.

WEESNER, F. M. External anatomy. In: KRISHNA, K. \& WEESNER, M. (Ed.). Biology of termites. New York: Academic Press, 1969. v.1, cap.2, p.1945.

WILSON, E. O. The insects societies. Cambridge: Belkanp Press, 1974. $548 \mathrm{p}$.

WOOD, T. G. \& PEARCE, M. J. Térmites in África: the environmental impact control measures and damage to crops, trees, rangeland and rural buildings. Sociobiology, v.19, n.1, p.221-234, 1991.

WOODROW, R. J. ; GRACE, J. K.; YATES III, J. R. Hawaii's termites - an identification guide. University of Hawaii at Manoa, 1999. 6p.

ZERBE, J. I. Wood as a material for conservation of energy. Forest Products Research Society - International conference, p.223-224, 1992. 